Portland State University

PDXScholar

11-21-1995

\title{
A Swamp in the Desert: Theory, Water Policy, and Malheur Lake Basin
}

Cristin R. Mandaville

Portland State University

Follow this and additional works at: https://pdxscholar.library.pdx.edu/open_access_etds

Part of the Geography Commons

Let us know how access to this document benefits you.

\section{Recommended Citation}

Mandaville, Cristin R., "A Swamp in the Desert: Theory, Water Policy, and Malheur Lake Basin" (1995). Dissertations and Theses. Paper 5278.

https://doi.org/10.15760/etd.7151

This Thesis is brought to you for free and open access. It has been accepted for inclusion in Dissertations and Theses by an authorized administrator of PDXScholar. Please contact us if we can make this document more accessible: pdxscholar@pdx.edu. 
THESIS APPROVAL

The abstract and thesis of Cristin R. Mandaville for the Master of Science in Geography were presented November 21,1995 , and accepted by the thesis committee and the department.

COMMITTEE APPROVALS:

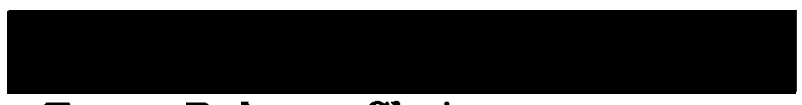

Teresa Bulman, Chair
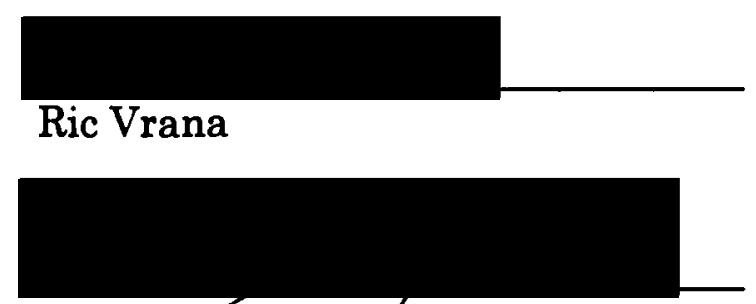

Daniel M. Johnson

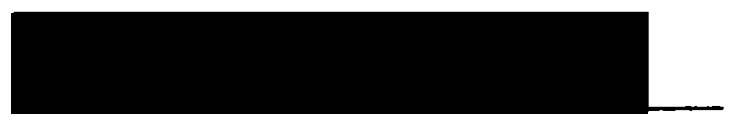

Ann Weikel

Representative of the Office of Graduate Studies

DEPARTMENT APPROVAL:

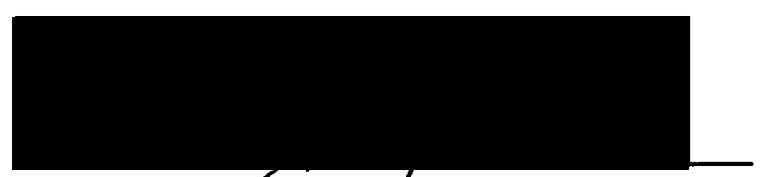

Daniel Johnson, Chair

Department of Geography

ACCEPTED FOR PORTLAND STATE UNIVERSITY BY THE LIBRARY

by

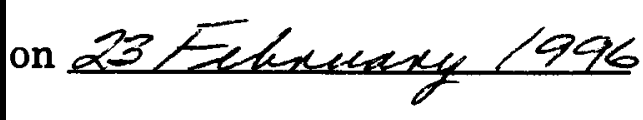




\begin{abstract}
An abstract of the thesis of Cristin R. Mandaville for the Master of Science in Geography presented November 21, 1995.
\end{abstract}

Title: A Swamp in the Desert: Theory, Water Policy, and Malheur Lake Basin

Two perspectives are debated in current United States water policy model development. One perspective calls for policy based on normative values, such as an environmental ethic. The second perspective calls for policy based on empirical, quantifiable values, for instance, economic benefits and costs. This theoretical debate arises from differing assumptions about what is problematic in contemporary water policy, and in turn gives rise to many water policy models. Developing such models ostensibly provides frameworks useful for developing real-world water policies. This paper proposes that these water policy models are not in fact useful frameworks for policy applications because the models do not accurately account for the actual circumstances confronting water policy makers. In 
order to illustrate this hypothesis, a comparison of two water policy models with a set of real-world policy circumstances is made here.

The two models, each representing one of the dominant theoretical perspectives, are taken from David Lewis Feldman's Water resources management: In search of an environmental ethic (1991) and Peter Rogers' America's water: Federal roles and responsibilities (1993). Feldman's model was selected to represent the normative perspective, and Rogers' model is selected to represent the empirical perspective. The real-world water policy circumstances selected for this study are those of Malheur Lake Basin, Oregon. This basin was selected because it provides the opportunity to consider a range of water policy issues and problems. This study shows that these two models do not offer adequate frameworks for applications. If water policy models are to provide useful frameworks for applications, model development must more closely consider actual cases. 
A SWAMP IN THE DESERT:

THEORY, WATER POLICY, AND MALHEUR LAKE BASIN

by

CRISTIN R. MANDAVILLE

A thesis submitted in partial fulfillment of the requirements for the degree of

\section{MASTER OF SCIENCE in GEOGRAPHY}

Portland State University 1996 


\section{ACKNOWLEDGEMENTS}

Many people have provided me with assistance while I worked on this project. Because such projects never occur in isolation, the only surprise is that these people assisted me knowingly and willingly. For taking time to provide excellent insights on Malheur Lake Basin circumstances, I thank in particular Gordon Bentley of the Burns District Bureau of Land Management and Dan Wallsworth of Malheur National Wildlife Refuge. For advice, editorial assistance, and personal support, I thank Todd Gilman, Janet Mandaville, and Jon Mandaville. For editorial comments on the maps included in this paper, I thank Chris Gillis and Dave Petterson.

Of course, the members of my committee deserve special thanks for teaching and support throughout my master's program. Ann Weikel taught the first graduate level course I took at Portland State, and graciously agreed to also participate on my thesis committee. Teresa Bulman, Dan Johnson, and Ric Vrana deserve particular thanks for their mentorship; my experience at Portland State would not have been the same without their participation. Carolyn Perry's patience and editorial assistance is also greatly appreciated. 
TABLE OF CONTENTS

PAGE

ACKNOWLEDGEMENTS . .................... ii

LIST OF FIGURES $\ldots \ldots \ldots \ldots \ldots \ldots \ldots \ldots \ldots \ldots$

\section{CHAPTER}

I INTRODUCTION $\ldots \ldots \ldots \ldots \ldots \ldots \ldots \ldots \ldots$

The Models $\ldots \ldots \ldots \ldots \ldots \ldots \ldots \ldots \ldots$

Malheur Lake Basin . . . . . . . . . . . . . . . . .4

Review of the Literature.............6

Policy Models versus Real-World Policy ........11

II TWO WATER POLICY MODELS $\ldots \ldots \ldots \ldots \ldots \ldots . \ldots$

Methodology ...................13

Two Water Policy Models. . . . . . . . . . . . . .14

Feldman's Water Policy Model . . . . . . . . . 15

Assumptions

Objectives and Methods

Rogers' Water Policy Model. . . . . . . . . . . . 29

Assumptions

Objectives and Methods 
III MALHEUR LAKE BASIN WATER POLICY. . . . . . . .46

Physical Factors of Water Policy. . . . . . . 46

Climate

Hydrology

Human Factors of Water Policy. . . . . . . . .65

Wildlife and Habitat

European Settlement Patterns and History

Governance and Planning

Interagency and Intergovernmental Conflicts

IV $\quad$ ANALYSIS. $\ldots \ldots \ldots \ldots \ldots \ldots \ldots \ldots \ldots \ldots$

Feldman's Model and Malheur Lake Basin . . . . . 89

Economics

Law

Politics

Objectives and Methods

Rogers' Model and Malheur Lake Basin . . . . . . 96

Economics

Law

Politics

Objectives

v CONCLUSION.................. 107

BIBLIOGRAPHY $\ldots \ldots \ldots \ldots \ldots \ldots \ldots \ldots \ldots \ldots \ldots \ldots \ldots \ldots \ldots \ldots \ldots \ldots$ 


\section{LIST OF FIGURES}

FIGURES

PAGE

1. Feldman's Water Policy Model $\ldots \ldots \ldots \ldots \ldots 16$

2. Rogers' Water Policy Model . . . . . . . . . . . . 30

3. Malheur Lake Basin, Oregon. . . . . . . . . . .47

4. Average Monthly Precipitation ............50

5. Isohyets of Malheur Lake Basin, Oregon .........51

6. Average Monthly Temperatures ............52

7. Annual Monthly Streamflows for the Silvies and Blitzen Rivers ...................55

8. Aquifers of Malheur Lake Basin, Oregon .........60 60

9. Streets of Burns and Hines, Oregon . . . . . . . 63

10. Property Ownership in Malheur Lake Basin, Oregon . 67

11. Agricultural Land in Malheur Lake Basin, Oregon. . . 72

12. Comparison of Two Policy Models and Malheur Lake Basin, Oregon . . . . . . . . . . . 86 


\section{CHAPTER I}

\section{INTRODUCTION}

Uncertainty has been a central concern in United States water policy history (Holmes 1972; Holmes 1979). The desire to include a measure of certainty in policy has led to policy model development. Two perspectives have dominated this model development, particularly in contemporary debate. One perspective advocates policy based on normative values, such as a social contract based on an environmental ethic. The second perspective calls for policy based on empirical values, for instance multi-objective plans based on quantitative assessments of benefits and costs. The models are based on differing assumptions about what is problematic in water policy. This paper hypothesizes that water policy models do not provide particularly useful frameworks for actual policy development, and that this is because the models do not accurately represent the circumstances of the real world.

This paper indicates that neither of the approaches evaluated herein can be applied to actual water policy cases. Elements from both models are found in the case studied, but the analysis indicates that even if the models 
were fully applied they would not result in achieving their stated objectives in this case or elsewhere. Further, both models overlook factors critical to water policy. In particular, the models fail to address crucial physical, political, and legal factors in actual water policy. These failures are illustrated by the circumstances of the case studied. Unless water policy model development is made useful, the value of its continued debate is questionable.

Both Feldman and Rogers define "water policy" as the entire complex of policies, plans, rules, and factors involved in water resources use and management. This definition is used in examining the case of Malheur Lake Basin (the "Basin") as well. The major factors involved in Basin water policy are considered in evaluating the Basin case.

\section{THE MODELS}

David Lewis Feldman's (1991) Water resources management: In search of an environmental ethic and Peter Rogers' (1993) America's water: Federal roles and responsibilities provide the models considered in this paper. Both perspectives are concerned with several common water resources problems, such as water quality protection and equitable distribution of the resource and the benefits produced by it. Both authors are also concerned with broader policy problems, including an abundance of 
involved institutions, regional administration, and intergovernmental relations. Both focus on the United States, and include discussions of economics, law, and politics in their models.

Nonetheless, the models are framed by the authors' very different perspectives, and are based on very different assumptions of policy problems and of what makes good policy. The normative perspective, represented in this study by Feldman's model, calls for a broad-based social acceptance of uncertainty regarding nature and natural values. The value of water must be assumed to be inherent, rather than assigned by society, and greater than its value as a commodity. Good water policy interferes minimally with the natural hydrologic cycle. Social equity is also inherently valuable in this perspective. The administrative system Feldman proposes consists of a national system of decentralized regional water authorities, controlled locally and based on watersheds.

The empirical perspective, represented in this study by Rogers' model, focuses on accounting for that which is known. Good water policy must consider water a commodity. Water distribution should be managed through market-based strategies to ensure balance in fiscal budgets and in water supply and demand. Environmental impacts of water policy should be considered in terms of quantifiable values, benefits, and costs. Rogers 
proposes establishing central federal authority over regional water administrations.

\section{MALHEUR LAKE BASIN}

A watershed basin in southeastern Oregon provides the case study examined in this paper. The watershed is Malheur Lake Basin, as defined by Oregon State Water Resources Department. Malheur Lake Basin ("Basin") water policy circumstances include a variety of physical and human factors, some of which are unique to the Basin and some of which can be generalized to other locations and situations. The factors considered in this study are not limited to those that parallel the factors addressed in the models. Instead, water policy in this Basin is described in terms of the concerns that dominate water resources and policy debates in the Basin.

In the Basin, water policy is determined by a few primary players based on certain assumptions. Agents with roles in determining water policy include federal agencies, Oregon, consumers, and private interests. Two broad interests, based on water usage, dominate Basin water policy. First, there exists within the Basin an interest in maintaining current economic, largely agricultural, activities and levels of productivity. Second, there is an interest in preserving and improving a large area of the Basin for wildlife habitat. The economy of the Basin is dominated by cattle 
ranching, which is generally considered to affect water quality and wetlands' habitats negatively (U. S. Fish and Wildlife Service 1994). At the same time, both residents and non-residents value the Basin wetlands and wildlife highly. These apparently opposing values developed over the history of European occupation of the basin. These assumptions sometimes lead to conflicts over water policy.

Controversy over grazing, the condition of public rangelands, and the effects on water quality began shortly after the arrival of the first ranchers in 1868. Early settlers came in the 1870 s to claim portions of the then vast grassland valleys. The greatest influx of settlers to the Basin, largely consisting of ranchers, occurred in the $1880 \mathrm{~s}$. By the turn of the century, the grasslands were dramatically degraded. Progressive Era conservationism, however, and concern for game and other migratory water birds, led to the establishment of Malheur National Wildlife Refuge in 1908. The area of the refuge was expanded in 1935 and again in 1941, and presently encompasses about 184,000 acres of wetlands.

An interior drainage basin in a semi-arid region, the Basin provides the opportunity to consider a wide range of water resources supply and demand issues, including floods and water shortages, agricultural productivity, and wildlife habitat preservation. The area often experiences both water shortages and flooding within a single water year or over several 
years. Ground water provides an important resource for the wetlands and municipal and domestic water supplies.

The key agents administering water policy in the Basin include three federal agencies - the United States Forest Service ("USFS"), Bureau of Land Management ("BLM"), and Fish and Wildlife Service ("USFWS") - and the State of Oregon. These are key agents because the federal agents own extensive land in the Basin, the USFWS holds senior water rights, and Oregon owns the water resources in the state.

Federal lands include rangelands (managed primarily by the BLM), forests (managed by the USFS), and wildlife refuges (managed by the USFWS). Local consumers generally value both the rangelands and the refuges highly. Thus, federal interests vary along the same lines as local, private interests. The roles of local jurisdictions in directly shaping water policy are minimal because of the state's authority over water and land use decisions, and the degree of federal land ownership. Therefore, local jurisdictions are not considered in this study.

\section{REVIEW OF THE LITERATURE}

Until the 1950s, U. S. water policy emphasized large water projects and structural basin development. This is generally considered to have undermined broad-based national interests and long-term sustainability of 
water supplies (Gottleib 1988; Mann 1975; Maass 1951; North, et al. 1981;

Reisner 1986). Since the 1950 s, an emphasis on improving water administration by increasing quantitative certainty coincided with an increasing concern with water quality and aquatic ecosystem health (Carson 1962; Ciriacy-Wantrup 1963; Cohon 1978; Eckstein 1958; Hanke and Davis 1973; James and Lee 1971; Maass, et al. 1962; Moore 1988; Moreell 1956; Welsh 1985; White 1969; Wolman and Bonem 1971).

More recently, water policy models are recommended as a means of preserving overall environmental quality, protecting biodiversity regionally, and distributing an important resource equitably (Anderson 1983; Doppelt, et al. 1993; Feldman 1991; Kellert, et al. 1991; National Research Council 1992; Organization for Economic Cooperation and Development 1989; Reisner and Bates 1990; Rogers 1993). The specifics of these models differ, but all call for increased public participation, for regional administration of water resources, and for better coordination of objectives and methods among agencies and organizations within and between water resources regions.

Geographers involved in water policy modeling have included Gilbert F. White, who, among his many endeavors, presented a classification of strategies of United State water policy (White 1969), considered recent wetlands policy developments (White 1991), and modeled the environmental 
impacts of the Aswan Dam (White 1988). Mathews (1984) applied geographic analysis to a consideration of water resources and law. Regional approaches have also played a role in geographers' analyses of water resources (Muckleston 1990; Sewell 1965; White 1986). Wilkinson (1990) modeled a water policy with a humanist approach for improving degraded western lands. Water management and administration with a demand management approach was modeled by Platt (1993), who also considered a demand management approach as applied by Massachusetts (1995).

Water policy models are currently developed within the context of a debate over two perspectives. The normative perspective calls for ideological consistency of and between water resources laws, institutions, and activities (Anderson 1983; Feldman 1991; Doppelt, et al. 1993; Organization for Economic Cooperation and Development 1989). Generally, this perspective also advocates decentralization. Feldman's normative perspective follows this tradition.

The empirical perspective claims to be based on feasibility (Rogers 1993; National Research Council 1992; North, et al. 1981). This perspective relies heavily on economic assessment and market forces, and yet also typically calls for strong central authority over the various interests in water policy. Rogers' perspective is in alignment with this tradition. 
Models considered but not selected for this study were rejected on various grounds. Anderson's (1983) model was deselected because it has been over a decade since its publication. White's (1969) classification scheme, though was rejected also for its publication date. Sewell's (1965) study of floods and the Frasier River Basin was not considered for this study because of the publication date. The criterion for selection of a recently published model was based on the intent to critique the current state of affairs within the water policy model debate.

Other models were rejected primarily based on the criteria of geographic scale and topical scope. The models selected for this study were required to address U.S. water policy comprehensively. Several models were rejected for their narrow scale or scope, including White's (1988) consideration of the Aswan Dam, Mathews (1984) consideration of geography and water law, Wilkinson's (1990) consideration of Western U. S. water resources concerns, and the National Research Council's (1990) model for improving the quality of aquatic ecosystems. The Organisation for Economic Cooperation and Development proposal for integrated, watershedbased water administration was rejected because of its wide geographic and topical focus on a variety of international issues (1989).

Studies of Malheur Lake Basin water resources issues have focused primarily on specialized scientific topics and the history of the ranching 
industry (Anonymous 1902; Brimlow 1951; French 1964; Fuste and McKenzie 1987; Horton, et al. 1983; Hubbard 1975; Hubbard 1989; Paulson, et al. 1991; Piper 1939; Rinella and Schuler 1992; Simpson 1987; U. S. Army Corps of Engineers 1987; Vorderstrasse and Garst 1987). Fewer studies have directly considered water resources policy and management concerns (Duebbert 1969; Klingeman, et al. 1971; Reinhardt 1992).

The State Water Resources Board's Malheur Lake Basin Report (1967) and Biennial Report (Oregon Water Resources Department 1992), Oregon's Water Rights Systems (Oregon Water Resources Department 1994), and the Strategic Water Management Plan (Oregon Water Resources Department 1995) provide the background for the description of state water policy in this paper.

Land use plans and program documents provide the background for federal water policy. The wildlife refuge documents include plans for Hart Mountain Antelope Refuge and Malheur Wildlife Refuge (Franklin, et al. 1972; U. S. Fish and Wildlife Service 1982; 1985; 1990; 1992; 1994). The largest area of land is managed by the Bureau of Land Management. Plans and information regarding BLM holdings and programs are also considered (U. S. Bureau of Land Management 1982; 1986; 1989; 1992a; 1992b; 1993a; 1993b; 1993c). The most recent public forest plans, though less important for water policy in the basin than either the USFWS or the BLM documents, 
are also considered herein (U. S. Forest Service 1991). Typically, the USFS and BLM interests regarding water tend to coincide, in favor of protecting economic productivity, and are in opposition to the USFWS, which favors protecting the environment.

\section{POLICY MODELS VERSUS REAL-WORLD POLICY}

As both Feldman (1991) and Rogers (1993) state, the best indication of success in policy models is to be found in examinations of actual policy cases. However, this study suggests that the model development debate does not offer frameworks useful for actual policy applications. In order to provide a framework useful for real-world policy applications, a water policy model would need to offer concrete and practical strategies for improving unpon existing policy. A useful model would encompass many of the general factors involved in actual water policy situations. Broadly, such a model would provide feasible strategies for water distribution, use, and hazard mitigation. Determining feasibility would require a comprehensive consideration of existing constraints on water resources. While a useful model might consider issues including social equity or federal authority, it would also include consideration of physical, political, and legal circumstances. As indicated by the models considered herein, models which overlook these circumstances or which are not feasible give existing 
constraints are not useful for applications. If water policy modeling is to do more that perpetuate a theoretical debate, justify certain jobs, and leverage certain political and academic platforms, it must bridge the gap between theory and application. 


\section{CHAPTER II}

\section{TWO WATER POLICY MODELS}

\section{METHODOLOGY}

Three steps comprise this study. First, the two opposing models are described in terms of specific assumptions, objectives, and methods. Second, a case in water policy is described in terms of its assumptions, objectives, and methods. Finally, the terms of the models are compared to the terms of the case in order to analyze the applicability of the models to the case. This comparison is qualitative.

The criteria for selecting these models included the representation of either the normative or the empirical perspective and fairly recent publication. The criteria also required certain similarities between the models, such as a national scale and attention to the concept of regional management. These criteria were established in order to facilitate the comparison to actual water policy circumstances. Malheur Lake Basin was selected based on criteria including: existing water policy concerns, representation of U.S. water policy interests in the form of federal agencies, 
representation of state and local interests, and a regional approach to water resources planning and management.

\section{TWO WATER POLICY MODELS}

Feldman and Rogers developed their models for water policy based on how they each perceive contemporary water policy and on what they each believe is the fundamental cause of water policy problems. Based on their assumptions, Feldman and Rogers develop frameworks for improving water policy, including specific objectives and methods for implementation. They each claim that implementing their respective policy models will lead to more socially-beneficial outcomes than are found in existing policy.

Although each author explicitly grounds his model in a philosophical perspective, each also focuses on a primary question that is essentially geographic. In debating questions about normative versus empirical perspectives in water policy, they both consider what scales are best for water administration. Feldman recommends increased pluralism in U.S. water policy, and Rogers recommends centralization. Both recommend regional administration of water, under jurisdictions other than the states. In order to compare the models with Malheur Lake Basin, it is necessary to distill the key components of each: assumptions, objectives, and methods. 


\section{FELDMAN'S WATER POLICY MODEL}

\section{Assumptions}

Feldman identifies the fundamental cause of problems in water resources policy as capitalism (Figure 1). His assumption is that capitalism defines a normative, socio-political ethic that is inherently detrimental to humans and their environment. The ethic of capitalism rests on core values "antithetical to conservation and preservation" (Feldman 1991, p. 205). Feldman believes capitalist motives impede individual, social, and natural teleological development. Such values, according to Feldman, include a commoditization of nature, an assumption of humanity's right to exploit nature, and unlimited individual freedoms: “[t]he ... willingness to rank individual economic liberty . . above the broad range of human needs" (Feldman 1991, p. 15) obviates the development of harmony within society and between society and nature.

Economics. One primary outcome of the capitalist ethic is that frequently the market is presumed to be the best means of making political decisions. Policy that results from the behavior of the market does not consider "non-economic values, ... local concerns and tradition, ... promises made to regions and ... the impact of policy upon present and future generations" (Feldman 1991, p. 2). Feldman contends that a water 


\begin{tabular}{|c|c|}
\hline \multicolumn{2}{|c|}{ ASSUMPTIONS } \\
\hline \multicolumn{2}{|c|}{ Capltalism is the root cause of water pollcy problems. } \\
\hline \multicolumn{2}{|c|}{ ECONOMICS } \\
\hline \multicolumn{2}{|c|}{$\begin{array}{l}\text { - Market does not make best policy decisions } \\
\text { - Public involvement is restricted by market } \\
\text { - Benefits and costs not distributed equitably by market }\end{array}$} \\
\hline \multicolumn{2}{|l|}{ LAW } \\
\hline \multirow{2}{*}{\multicolumn{2}{|c|}{$\begin{array}{l}\text { Water rights are property rights, preventing: } \\
\text { - Balanced supply and demand } \\
\text { - Protection of ground water } \\
\text { - Water rights transfers }\end{array}$}} \\
\hline & \\
\hline \multicolumn{2}{|c|}{ POLITICS } \\
\hline \multirow{2}{*}{\multicolumn{2}{|c|}{$\begin{array}{l}\text { - Narrow interests are represented } \\
\text { - Decision-making is inconsistent } \\
\text { - Accountability is lacking }\end{array}$}} \\
\hline & \\
\hline \multicolumn{2}{|c|}{$\begin{array}{l}\text { Replace capitalist ethic with an environmental ethic, } \\
\text { providing rules for: }\end{array}$} \\
\hline \multirow{2}{*}{\multicolumn{2}{|c|}{$\begin{array}{l}\text { - Fair and equitable use } \\
\text { - Full payment for use } \\
\text { - Use that does not result in harm } \\
\text { METHODS }\end{array}$}} \\
\hline & \\
\hline \multicolumn{2}{|c|}{$\begin{array}{l}\text { Increase pluralism } \\
\text { - Create political-hydrologic regional (watershed) } \\
\text { administrations } \\
\text { - Establish structural efficlency rule } \\
\text { - Include representation of all interests } \\
\text { - Require payments to be in proportion to benefits }\end{array}$} \\
\hline $\begin{array}{r}\text { Gain } t \\
-E \\
-F\end{array}$ & $\begin{array}{l}\text { ad-based acceptance of social contract } \\
\text { ed on decision-making rules, not end-states } \\
\text { nalizing principles of the environmental ethic }\end{array}$ \\
\hline
\end{tabular}

Figure 1. Feldman's water policy model. 
policy based on market forces inevitably encompasses only narrow interests. Such policy does not satisfy a criterion of justice, and promotes only the pre-existing preferences of engineers, planners, and water resource beneficiaries.

Related to the public faith in market-driven decisions is confidence in the use of benefit-cost analyses for measuring the efficiency of policies. Feldman finds the prevailing concepts of efficiency, and the use of benefitcost analysis to justify and support these concepts, troubling. Benefit-cost analyses lead to several specific problems. First, they are intended for use in comparing and evaluating policy alternatives. Feldman claims that development and consideration of such alternatives rarely occurs in reality. Second, only a few dominant interests are represented, both in the conducting and accounting of such analyses. Third, the criterion of structural efficiency, which requires that the benefit of one person does not result in harm to another person, is rarely considered. Benefit-cost analysis is problematic because it "inadequately accounts for environmental impact and ... it ignores the range of concerns people have about the uses of natural resources" (Feldman 1991, p. 6).

By failing to consider structural efficiency and to transcend market forces, water policy that is rooted in capitalism derives short-term benefits for limited interests, claims Feldman. The existing system obscures rather 
than elucidates the whole public interest, and is both exploitative and inequitable. There is no incentive in the existing system to pursue less costly (in terms of both economic and non-economic costs of exploitative use) and more equitable water policy alternatives, alleges Feldman. Distributive politics and the use of water resources to develop regional economies, through regional water projects, embody this approach to water policy. In addition to regional inequities, such projects intend to optimize economic efficiency, not structural efficiency, by developing multiple-use objectives. These multiple uses, however, only address the particular interests of certain beneficiaries, rather than the interests of all those responsible for paying for, or otherwise incurring a loss due to, the construction of the projects.

Law. Founding water policy on capitalism and its ethical principles affects realms beyond merely the economic. Expressing this ethic in the application of property rights to water becomes problematic in riparian and appropriative systems alike, and is particularly thorny in ground water law. The property rights approach to water law leads to many outcomes, few of which encourage conservative use or equitable distribution of the resource or the benefits derived from the resource.

Feldman alleges there are three primary failures of the property rights systems of water law. First, supply and demand, the physical 
attributes of water available for use and water used, are not balanced.

Second, ground water is not adequately protected. Feldman does not mention that ground water laws evolved prior to scientific understanding of the resource, and thus overlooks that this failure might be one of science or policy rather than of law. The third failure of water law is that water rights transfers are not typically feasible. The legal failures, claims Feldman, are exacerbated by the "fragmentation of authority" and legal rules, which differ from state to state (Feldman 1991, p. 27).

The failure of water law systems to balance use and availability results from a fallacy that water supplies for multiple concurrent uses are available (Feldman 1991). Thus, according to Feldman, while the economics of water rest on the assumption that markets are good decision-makers, the law of water assumes water supplies are fairly abundant, renewable, and available for many simultaneous uses. Doctrines of reasonable and beneficial use, and correlative rights, do not overcome discrepancies between use and availability, claims Feldman. These legal principles are limited due to monitoring problems, unclear definitions of the reasonable and beneficial use doctrines, and the highly competitive environment surrounding the water rights systems. Monitoring problems are not detailed by Feldman, but might be assumed to include the lack of measurement of the use and waste of water, such as water metering. 
The second failure of water law lies in ground water rules that are based on the premise that ownership of an area of land means ownership of that land surface and of everything under it. This leads to what is called the 'power of the pump,' whereby landowners pump as much ground water as they can with whatever size of pump they buy. This is now tempered in some states by doctrines of reasonable use and correlative rights, or by appropriative permitting rules for ground water in some cases. Reasonable use and correlative rights doctrines limit each individual's use by disallowing harm to neighboring water users' and may allow water use only in proportion to the area of land owned. As with prior appropriation systems of law, a few states (including Oregon) require permits to use ground water, with some uses (domestic or stock watering) excluded. These permits are issued according to roughly the same principles as surface water rights under prior appropriation. Feldman argues ground water laws, nonetheless, rarely foster equitability and generally prevent protection of aquifers from overdrafts and contamination.

Finally, neither riparian nor appropriative systems provide adequate standards and rules for the legal transfer of water rights. Typically, water rights are legally transferable only with the sale of the land to which they are tied, either by geography (under riparian systems) or by permit (under prior appropriation systems). This failure of water law is illustrated by two 
specific problems with prior appropriation systems, claims Feldman. Under drought conditions, junior appropriators receive no water while senior appropriators receive full allocations, which is a social inequality inherent to the system. Further, there is a disincentive for conservative use under appropriative systems due to the so-called 'use-it or lose-it' doctrine. Effectively, this is a statute of limitations on the non-use of a water right, and after a certain period of non-use transpires, the water right reverts to the state. This encourages water rights holders to use all of their allocated water, even if not needed, in order to retain the valuable right. This also discourages conservation and equitable distribution.

Thus, Feldman contends, due to these failures of a water law founded on principles of private property, and based on the capitalist ethic, equitable and sustainable uses of water are prevented rather than encouraged. Specifically, water use exceeds availability, ground water quality and quantity declines, and water rights are not easily transferable to allow for redistribution in times of shortages, excesses, or to achieve alternate preferred objectives.

Politics. Feldman describes many problematic outcomes of capitalist water policy in the political arena. These outcomes include: exclusion of certain interests from decision-making, ad hoc decision-making, a lack of coherency in policy, a lack of accountability for policy, and a proliferation of 
self-interested institutions. Because they are inherent in the existing capitalist structure, Feldman does not think that even major institutional reforms can resolve or improve these situations.

The form of democracy that results from the capitalist ethic, which Feldman criticizes, is characterized by numerous competitive, selfinterested groups, and a popularly-held belief that this method of decisionmaking (as with market forces) leads to preferable results. The political arena assumes participants are defending and trading-off preferences. The actual result, says Feldman, is a "politically narrow struggle for bureaucratic survival and interest group aggrandizement" (Feldman 1991, p.3). The process excludes, obscures, and marginalizes the true, broad-based public interest, entrenches participants in narrow agendas, and does not allow the consideration of a wide range of policy alternatives.

Feldman further points to the ad hoc nature of policy as being one problematic result of an assumption of capitalism. Situations that are visible and promoted by vocal, politically-prominent, interests receive attention. Decisions are typically justified by utilitarian criteria: the most benefit for the most people at the least economic cost and in the shortest time. However, argues Feldman, long-range planning, which considers noneconomic values and broad public interests, is not a part of this ad hoc type of decision-making (Feldman 1991, p. 7). Comprehensive planning may be 
more coherent, Feldman concedes. However, the historically dominant method of addressing water-related concerns has been without "regard to systematically established national priorities based upon a political theory of the environment" (Feldman 1991, p. 10). Without such grounding in a political theory of the environment, and domination instead by a capitalist ethic, most comprehensive planning efforts have failed to improve upon ad hoc planning, Feldman believes.

The same forces that prevent the installation of coherency in water resources policy prevent the designation of responsibility and enforcement of obligations by beneficiaries to compensate non-beneficiaries for losses and impacts. There is no obligation for the beneficiaries of water resources policies to be accountable for impacts to human and environmental needs outside their narrow interests. Feldman believes that not only should beneficiaries be obligated to repay benefactors, but also that it is not justifiable for individuals "to refuse to allow the needs of society to restrict their use of certain resources" (Feldman 1991, p.14).

Feldman also argues that there are simply too many institutions involved in water resources, each with different interests and jurisdictions, leading to fragmented, over-lapping authority, constituency-based decisionmaking, and a bureaucratic goal of institutional survival. These institutions include agencies at all levels of government. Any policy-making or 
politically influential organization is also a candidate for this group. These institutions construct a culture of experts, such as engineers and economists, and base decisions on expert-opinions, further obviating public participation. Public participation is sacrificed, and public interest obscured, by the proliferation of these institutions on the political landscape.

The false belief that institutional reforms will lead to improved policy is coupled with the problems of numerous involved institutions, claims Feldman. Interagency conflicts continue when reorganization is attempted, because the values of organizational members do not change with centralization, consolidation, or coordination. Feldman believes that differences are intensified when efforts are made to achieve consensus through reforms or mandates. Feldman asks whether institutional reform and increased consensus will provide the most flexibility and innovation in policy development.

\section{Objectives and Methods}

An alternative to the capitalist ethic forms the foundation of Feldman's objectives and methods. This alternative is an environmental ethic, and the basic objectives of this ethic are:

...(1) the rights of users to fair and equal use of the water, (2) the interdependency of natural resources, based upon the character and disposition of these resources in a region as well as historical patterns of development, and (3) the obligations of users to abide by the rules for allocation of water and of the 
costs of locating, supplying, cleaning and transporting water. . . (4) No change in use, allocation, or development would be permitted unless it could be demonstrated that the change that makes some members of society better off would not make others, whether in the same or another water resources region, worse off (Feldman 1991, p. 196).

The main impediment Feldman identifies to the development of a normative environmental ethic is the pre-existing normative capitalist ethic that encourages the view of water as a commodity with a primary value in advancing individuals' and civilizations' wealth.

Feldman's believes that establishing an ethically defensible natural resources policy is a crucial task facing society. Further, Feldman states that:

... an ethically defensible natural resources policy is one that satisfies a broad range of human needs, from survival and biological exigency to an enlightened existence in harmony with one's inner character, with others, and with nature. Implicit in the assumption is that a theory of justice should encompass natural resources as well as people ... In order to ensure the satisfaction of this range of human needs, the teleological development of people requires an enlightened regard for the distribution, use, and potential for abuse of natural resources. In addition, nature is intrinsically valuable in its own right because of its own telos, or purpose. Every natural resource has a place in the unity and order of the physical world (Feldman 1991, p. 21-22).

Water policy should account for both environmental and social costs incurred by water use and management as well as represent all possible interests. Feldman leaves many terms undefined. For instance, what he 
means by "enlightened," or the "needs" of humanity and nature for teleological development, is not clear.

Feldman's model poses four objectives of such an ethically defensible water policy and two primary methods for achieving these objectives. Increasing pluralism is the first method, and this consists of establishing a viable administrative system of political-hydrologic regions. The second method, establishing a social contract, provides rules and procedures of decision-making.

Feldman credits Gilbert White with the idea that flexibility and innovation are fostered in an environment rife with opposing views and interests. He expands on this idea with the claim that flexibility, experiment, and innovation are encouraged with a high degree of administrative pluralism. Feldman believes that it is not contradictory to both increase pluralism and establish a normative, environmental ethic. In fact, he believes his normative ethic would nurture pluralism, unlike the capitalist ethic. Specifically, Feldman recommends creating regional political-hydrological administrations with rules and decision-making procedures and authority. These would replace existing state systems of water law and administration. Replacing existing state systems of water law, Feldman believes, would resolve the failures he perceives in those systems. 
Feldman proposes the division of political-hydrologic regions based on watershed basins, with boundaries and sizes defined with a consideration of both cultural and natural factors. These regions would necessarily provide for inclusion and expression of a wide range of competing values. Further, the regional approach would allow for the definition of "real, discernible needs based upon our intuitive concepts of justice (clean, safe, fairly abundant water priced affordably so as to cover the cost of supply and transit)" (Feldman 1991, p.50). The true broad range of public interests is accommodated by the pooling of available resources within regions for the mutual, equitable benefit of all users. Feldman believes that this is not possible under the existing state systems because these were developed out of the capitalist ethic.

Feldman's regional administrations would contain operations subsystems similar to publicly-owned utilities. These administrations would be guided by rules set forth in a social contract. The social contract, either tacitly accepted or in constitutional form, sets forth the rules for decisionmaking within the regional system (Feldman 1991, p. 73). Feldman derives these rules from his environmental ethic. First, residents are entitled to certain specific rights and obligated by certain duties. Such rights include fair distribution and equal treatment, and duties include full payment of costs incurred by water users and beneficiaries. Water subsidies supported 
by non-beneficiaries and non-users would cease. Also, rules for determining and maintaining the regional boundaries would be included. These would accommodate both hydrological and cultural patterns, such as watershed characteristics and settlement patterns. While actual decisions would be flexible over time, the rules for decision-making would be fairly static. Perhaps most importantly, the rules ". . would [serve to] establish the priorities for allocation, the management of water resources, and the criteria for construction projects and for modifications to river basins and ground water resources" (Feldman 1991, p. 78). These rules would require that any viable plan or decision meet the criteria of structural efficiency.

Feldman's model emphasizes specifying rules and principles, rather than empirically measurable end-states. His approach is qualitative, not quantitative. Thus, the regional system would be both flexible and coherent. For example, instead of locking water rights to specific uses and locations, a standard set of water allocation rules would provide for changing needs and circumstances. Water distributions would not exclude some users during shortages, nor would certain new uses be excluded because historic overallocations are legally binding. 


\section{ROGERS' WATER POLICY MODEL}

\section{Assumptions}

Rogers' view of the fundamental problem in water resources policy is very different from Feldman's. Rogers locates the primary problem of water policy with the public's perception of water resources issues and the unrealistic expectations created by those perceptions (Figure 2). His goal in developing his model is to illustrate "a . . policy stance that will allow the myriad current and proposed ... activities to work together coherently without sudden major shifts" (Rogers 1993, p. 7). Further, he believes that education, of adults as well as children, is the only way to fully overcome the problems that currently arise in water resources policy. Unlike Feldman, he believes the crucial response to problems in policy is institutional reform at all levels of government, combined with improved definition of agency roles and responsibilities.

Unrealistic expectations for water supplies arise from increasing affluence in society. Rogers claims that:

Affluence leads first to a rise in the quantities of water used by each individual and his or her support systems, and second to a change in attitude toward the environment, from a strictly utilitarian concern for short-term human survival to an appreciation of the need for long-term sustainability of the aquatic ecosystem (Rogers 1993, p. 2). 


\begin{tabular}{|c|}
\hline ASSUMPTIONS \\
\hline Public perception is the root cause water policy problems. \\
ECONOMICS \\
- Unrealistic quality and quantity expectations \\
- Beneficiaries do not pay complete costs \\
- Inaccurate water pricing causes water shortages \\
LAW $\quad$ Federal legislation is required preventing: \\
$\quad$ - Ground water contamination \\
POLITICS \\
- Public and environmental health compete (and should not) \\
- Infrastructure definition (and accounting) do not include \\
maintenance and operations \\
- Interagency relations are conficting, paralyzing pollcy \\
processes \\
OBJECTIVES \\
\hline - Balance the water budget: fiscal and supply-and-demand \\
- Define governmental roles, consolidate and centralize water \\
administration \\
- Define and enforce water quality standards \\
- Educate the public \\
- Privatize water; manage water as a commodity \\
- Centralize water administration a federal water council \\
\hline
\end{tabular}

Figure 2. Rogers' water policy model. 
Further, costs increase per unit as the demands and expectations increase; likewise, the amount of benefit derived from ever-increasing spending at some point begins to decrease. Rogers does not think it is reasonable to spend money eliminating every minor contaminant from water, whether or not harmful, when it might be more productively spent improving other areas of public health.

Like Feldman, Rogers develops an argument for his model of water policy in terms of current economic, legal, and political concerns. Far less critical of the current state of affairs in water policy than is Feldman, Rogers states that he believes the existing system to be generally successful, though needful of reforms.

Economics. Rogers points to high and steadily increasing water costs as an indication of unrealistic public expectations for water supplies and water quality. Total spending for water resources development through $U$. S. history, he estimates, has been about $\$ 400$ billion. To maintain water supplies and quality at current standards, spending from 1985 through the end of the millennium would require an additional $\$ 200$ billion. Total spending on water resources and related programs in 1992, including federal, state, local, and private expenditures, was approximately $\$ 84$ billion, of which about one-third was federal funds. Much of this money is expended assuring that water is a renewable resource. This raises two 
questions crucial to Rogers: 'how much is enough?,' and how clean is clean enough?'

Another problematic economic issue under the existing system is the method by which costs are shared. Rogers believes cost sharing requirements are a good start. However, costs continue to accrue disproportionately to federal and state authorities, rather than directly to local beneficiaries. This allows for involvement of higher authorities in the direction of local water projects, but nonetheless is not entirely equitable. Inequities between who pays for and who gains from water resources can lead to highly undesirable consequences, according to Rogers.

One consequence of such inequities, when combined with inaccurate water pricing, is water shortages. Rogers believes water shortages are primarily an economic, rather than a physical, phenomenon:

Improper pricing of water, rather than inadequacy of supply, is most often the chief culprit in water shortages. Charging users what water really costs to produce, manage, treat, deliver, and dispose of after use is so sensible a concept that it hardly merits elaboration. But the fact is that few water delivery systems follow such a policy today (Rogers 1993, p. 185).

This perspective illustrates Rogers' belief that water policy and administration comprise an industry, whether managed as one or not. As an industry based on a particular commodity, it is subject primarily to market forces and only secondarily to natural forces. Rogers acknowledges that 
market and natural forces are interwoven, but he does not account for natural factors, such as floods or droughts, in his model.

Law. Rogers focuses on the regulatory role of federal laws in mitigation of environmental problems, rather than on the state riparian and prior appropriation systems of legal property rights in water, as did Feldman. Rogers accepts a property rights system of water law, and advocates privatization of some currently public functions and a regulated free-market approach to water policy. Nonetheless, he believes treatment of water with a strictly property rights-free market system is not adequate. He points to the success of federal regulation in reducing point-source pollution over the last two decades as an example of the potential for effectiveness of using environmental regulations to constrain market forces.

Rogers believes that two water regulation challenges currently face Congress. First, ground water protection has not been legislated. Though considered urgent for some time, ground water use and contamination remain largely unregulated. Ground water supplies are increasingly relied upon, yet no national objectives exist to lead states towards implementation of ground water plans and regulations. Second, the federal government does not provide adequate leadership to state and local governments by directing efforts to control non-point source pollution. Lacking federal legislation, limited action will occur at a local level to improve situations regarding 
ground water and non-point source pollution, Roger alleges, because subjectivity and local interests cannot be effectively transcended by local jurisdictions.

Politics. Politics is the realm, according to Rogers, wherein society sets and attempts to implement goals. Rogers indicates several problematic and neglected areas in the political realm. The primary weakness in each of the areas is in the poor definition of standards, priorities, and government roles. The areas Rogers discusses are: public versus environmental health, infrastructure, education and research, and intergovernmental relations.

The public's expectations for environmental quality fall into the political realm, as do questions of public health; both connect to water quality and quantity issues. As expectations for improvements in environmental quality and public health increase, so expectations for water quality and renewability also increase. However, Rogers indicates that priorities in environmental quality and public health, though often related, are sometimes in opposition; he notes that various programs sometimes compete for funds. Public awareness of both connections and competition between environmental quality and public health must be raised to begin addressing questions of 'how much is enough,' and 'how clean is clean enough.' Clear definition of and improved consensus about these questions will go far towards setting widely acceptable priorities for water. 
Water infrastructure, including delivery and waste water treatment systems, navigation and irrigation structures, hydropower, and flood control, is not adequately maintained, claims Rogers. Urban delivery and sewage systems are frequently leaky and of insufficient capacity for stormwater run-off. Rural delivery systems and irrigation practices are often wasteful; new technology might provide significant improvements. Irrigation runoff is by-and-large not regulated and monitored. Dams, reservoirs, and related large water-project structures are costly to build and maintain. Deciding to keep infrastructure in good repair, determining who pays the costs, and overseeing maintenance projects is the responsibility of political agencies. However, governments frequently do not prioritize this maintenance, nor do they consistently appropriate adequate funds to support sound infrastructure in good repair.

Rogers claims this stems from a lack of the political will and consistency to set and hold to consistent long-term goals. All too often, the background clamor of relatively short-term demands and crises supersedes long-term policy decisions. Rogers believes it is critical to maintain longterm policy objectives, and to minimize capitulation to short-terms demands inconsistent with these objectives.

Government agencies at all levels establish information systems and perform research activities, yet lapse in coordinating those efforts, asserts 
Rogers. Nor is information readily accessible and widely available. In the water policy arena particularly, centralization and coordination are important to ensure public access to and awareness of current research and findings, as well as to minimize agency overlap and redundancy, and to improve inter-agency communications.

Of particular concern to Rogers are jurisdictional conflicts and interagency relations. Rogers refers to differences between physical regions on one hand and political regions on the other hand. An example is that the geographic variation of hydrology and climate factors across the nation does not correspond directly to the geographic variation in jurisdictions with authority over water resources, the states. This is fundamentally a question about the best scale at which to manage water resources, and Rogers proposes federal-level policy-setting combined with local implementation and enforcement. This differs from the existing system because states were not established based on locally meaningful cultural and natural factors, claims Rogers.

Further, the existing system lacks a single central authority over water policy that might settle conflicts of interest through establishing national priorities and procedures. A lack of physically and culturally "meaningful regionalism" (Rogers 1993, p.14) contributes to problematic intergovernmental relations, believes Rogers. Tension between different 
levels of government (federal, state, and local) arises from differences in scale as well as from different interests and preferences. Friction also occurs among agencies and organizations at the same general level.

The increasing number of well-organized interests involved in water policy and management also contributes to difficult interagency relations. Though such an increase in interests may be legitimate, Rogers believes it can paralyze the political process. Effective negotiations and compromises are wrought more slowly, if at all, with increased participants, particularly when those participants disagree. Problems in inter-agency relations due to the plurality of organized interests are exacerbated by a lack of incentives for coordinated behavior and consensus. Instead, competition and selfinterest of agencies and organizations are often heightened through a policy process involving too many players and too little coordination.

\section{Objectives and Methods}

Objectives and methods of Rogers' model emphasize institutional reforms. The objectives include: 1) complete payment of water costs by beneficiaries, 2) definition and centralization of administrative roles, 3) definition and enforcement water quality standards, and 4) improvement of public education about water issues. The first objective Rogers describes rests on the premise that costs of water must be completely paid for by 
users. Rogers vehemently opposes the concept of treating water as a public good that should be free. Balancing expenditures for water with revenues from water is also crucial to Rogers' proposal. Rogers mentions the issue of equitable distribution of water resources, although he does not explain how such equitability would be achieved. Social equity is not addressed as a policy objective or standard. Lacking such an equity objective or standard, Rogers is susceptible to the criticism that his pay-for-use objective is regressive. Feldman's structural efficiency requirement in his payment-foruse objective allows him to dodge this criticism.

Rogers alleges that if federally or state held water "creates a benefit, [then] the ...government has a claim" (Rogers 1993, p. 189) and that the "costs [of water] should be recovered in the price paid by beneficiaries" (Rogers 1993, p. 193). Rogers recommends eliminating the gap between federally subsidized rates paid by local beneficiaries and actual market rates. All users, regardless, should pay equal, full market prices for the same resources. Costs might vary based on origin of the supply and transportation costs, for instance, but not on user characteristics (municipal, agricultural, e.g.). Accurately pricing water obviates the need for subsidies. Relevant external costs internalized will yield accurate water pricing, and thus the incentive to conserve. Rogers also recommends charging for direct use of resources and facilities and for equipment used to 
enjoy those resources and facilities. For example, a surcharge would accrue on prices of boats and fishing equipment, and user fees would apply on federal and state waters.

Further, under Rogers' framework, the term 'infrastructure' would expand. Institutional, operational, and maintenance attributes would be included with elements of the physical water infrastructure, such as sewers, mains, dams, and channels. The organizational attributes would be subject to direct charges or taxes, as would the physical attributes. For example, a direct tax on water use of 5 cents on 1,000 gallons of drinking water and the same tax on waste water would raise more than 1.5 billion dollars each year. The revenues raised from charging for the true costs of water would be kept in a depository, a "National Water Trust Fund" (Rogers 1993, p. 189). This institution might also be responsible for guaranteeing the preservation of other capital assets, such as the water infrastructure. Rogers suggests a federal water council manage this fund.

Rogers advocates water markets that are governed by national standards for ensuring equitable transfers and least-cost sources of supplies to users. Whereas the existing system limits water allocations to specified uses and locations, a water market would allow for flexible water allocations. Water rights could be transferred according to regulated transactions. Federal regulations would guarantee that transactions result 
in a net balance or increase in social benefits, Rogers claims. This would allow water to be managed as the commodity Rogers believes it is.

However, Rogers cautions:

... the market approach is far from well accepted in the United States today. It can run afoul of the concept that water should be freely available to all, and the in-stream water for fish and wildlife in particular, should be provided at no cost. The practice of making a profit from water sales, or even building a sinking fund from revenue surpluses in anticipation of future needs, is foreign to many purveyors, offensive to many of their constituencies, and frequently illegal. And proper pricing can encounter a firestorm of political protest, since the ultimate step is apt to be at least a doubling of prevailing rates (Rogers 1993, p. 186).

The next objective Rogers discusses is the need to clearly define, centralize, and coordinate government roles and responsibilities. Government agencies and organizations would be consolidated and coordinated by a central, federal-level water agency. Such an agency would perhaps fall under the direction of the president, and be organized as a council of appointees. The organization would be structured so council members would be free of other agency responsibilities and independent of competing agencies' missions. This council would formulate national water policy, coordinate water resources planning and management, and manage the federal water research and information programs. Such a national 
council would be established by legislation and would direct regional water authorities.

Regions must be meaningful to be effective, however. Because social development takes place in a political, economic, and cultural context, rather than, for instance, along watersheds and according solely to hydrology, watershed management is not the framework Rogers favors. Instead, regions comprising a complex set of physical and cultural characteristics are in order. Establishing meaningful regionalism in water administration is challenging because of the spatial differences between administrative jurisdictions and natural watersheds. This difference should be resolved for efficient and effective management, according to Rogers. Meaningful regions must be determined by local concerns, in accordance with state water law and federal regulation. For example, problem-sheds, regions aggregated based on specific water resources problems, would be more meaningful regions than watersheds, according to Rogers. In such problem-sheds, Rogers proposes a regional system of water policy and planning that considers cultural factors and natural factors that are of value and concern to humans. Defined at the local level, problem-sheds would be aggregated regionally, and would fall under the authority of the proposed federal water council. The relationship of problem-sheds to 
existing local, state, and federal jurisdictions is not defined in Rogers' discussion.

Rogers refers obliquely to consolidating existing government agencies and organizations. The proliferation of water-related agencies and committees in the executive and congressional branches of government is a serious concern of Rogers'. However, the closest he comes to making a specific recommendation is to say that:

... the obvious solution in each instance is a measure of consolidation: reform of the committee structure in Congress, and reorganization of the executive branch agencies .... the next best approach would be efforts at improved coordination among joint authorizing committees of the House and Senate (Rogers 1993, p. 17).

Centralization of the institutions conducting research and maintaining data is also a part of this objective. Decision-making at all levels of government requires accessible, current, coordinated, and adequate information on water and policy topics. This would be achieved by establishing and funding a centralized water research and information program, directed by the federal water council. This program would coordinate existing research programs as well. Additionally, some public education programs, in the form of public forums held regionally, would be one means of disseminating information from the researchers to the public. 
Protection of water quality through legislation is the third objective of Rogers' model. Specific issues he believes require immediate attention are: assessment and protection of ground water, wetlands, in-stream flows, and water quality. Rogers believes wetlands' issues in particular have good potential for unifying administrative efforts. This goal is to be achieved by clarifying reasonable standards, enacting federal regulations, and implementing these locally. Water quality regulations must be evaluated in conjunction with assessments of true costs and benefits.

The final and fourth objective of Rogers' model addresses the problem of public perceptions and unrealistic expectations. Rogers believes a national public education program, coordinated by the federal water council, would begin to resolve the fundamental problem of public expectations exceeding practical reality. Such an education program must contain not only curriculum modifications directed towards school children, but also programs directed towards adults. Professionals and individuals involved in water resources administration and management in particular must be provided with sound and complete information in order to make good decisions.

Rogers' program consists of "a series of regional forums ... held around the nation to link the federal water administrators with their state, local, and private counterparts" (Rogers 1993, p. 209). These forums would 
be open to the public, and sponsorship would be encouraged from nongovernmental organizations, including civic, research, and professional organizations. It would provide an avenue for public education and also would expose federal policy-makers to regional concerns and issues. Several specific and important issues would comprise forum topics, including: water law, water quality, land use, drought, financing, ground water protection, non-point source pollution, wetlands, and in-stream flows.

Many of the concerns Rogers raises, objectives he poses, and methods he recommends are similar to those of Feldman. For example, both are concerned with balancing the expenditures and revenues of water and with ending water subsidies. Both seek to minimize interagency conflicts and the paralysis that results from existing bureaucratic systems. Also, both envision a new regional system as the best method of improving water administration and management.

However, Rogers' and Feldman's models diverge in several significant ways. Feldman believes that the consideration of water as a commodity is highly problematic and instead water must be assessed by non-economic as well as economic values. Rogers believes that increasing the involvement of the market in water resources administration and management will solve economic problems. Feldman thinks that increasing pluralism and authority locally will break up the institutionalized conflicts of interest, thereby 
resolving the problem. Rogers thinks that interagency and interorganizational conflicts can be resolved by centralization and coordination federally. Feldman models a regional system of water administration based on primarily natural factors, with some consideration of cultural factors. Rogers models a regional system of water administration based on cultural factors and factors of nature as they are assigned value culturally. Finally, Feldman's model relies primarily on ethics and Rogers' model ultimately relies largely on economics. 


\section{CHAPTER III}

\section{MALHEUR LAKE BASIN WATER POLICY}

Rendering the water resources and water policy of Malheur Lake Basin ("Basin") in terms of simplified physical and human factors will enable the comparison with Feldman's and Rogers' models. These factors include a consideration of the assumptions, objectives, and methods for water policy development and implementation, but do not exclude additional descriptive information necessary to an understanding of Basin water policy. The physical factors are of central importance to Basin water resources and policy concerns. In many ways, Basin hydrology and climate determine the character of Basin water policy. Human activities, of course, are also a central determinant of Basin water policy.

\section{PHYSICAL FACTORS OF WATER POLICY}

Malheur Lake Basin is the largest hydrologically-closed basin in the State of Oregon, and contains wide, high plains, gently-sloped valleys, steeply-walled canyons and high mountains. The peak elevation is 9,670 feet at Steens Mountain, and the lowest elevation is 4,025 feet in Alvord Desert (Figure 3). The Basin combines features of both deserts and 


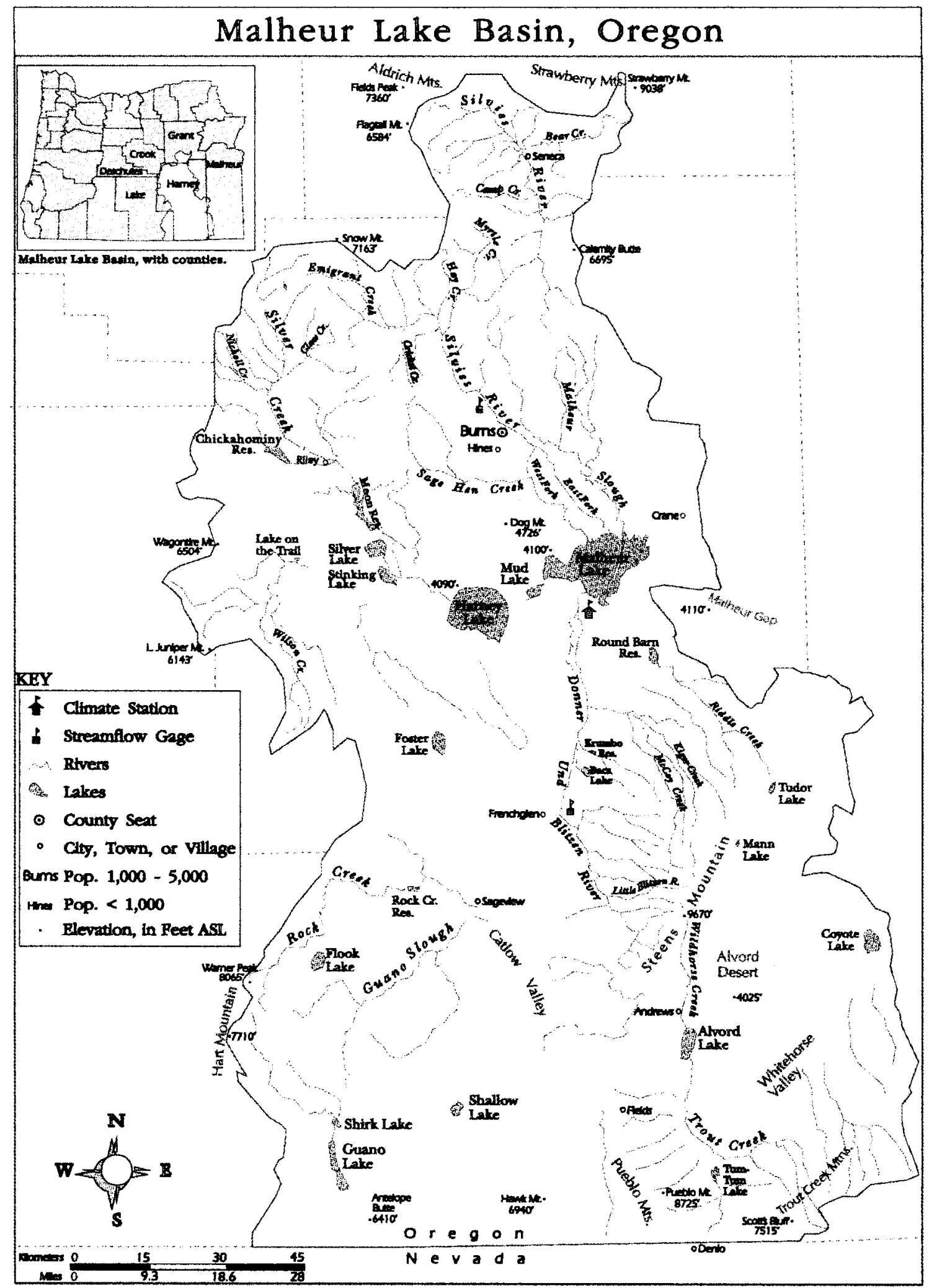

Figure 3. Malheur Lake Basin, Oregon. Major lakes, streams, and selected geographic features, based on data from BLM. 
wetlands. It contains one of the largest inland wetlands in the nation, and one of the most important nesting grounds for the greater sandhill crane (Rinella and Schuler 1992). Two national wildlife refuges, several wilderness study areas, and a Wild and Scenic River are only a few of the important reserves and recreation areas in the Basin. Yet, the primary economic activity in the Basin is cattle ranching.

The two land uses, ranching and wildlife habitat, often compete for water resources in the Basin. This results from both physical and cultural factors. Conflicts between the two uses are central to water policy development by policy makers, as are physical constraints on water resources. Physical factors playing a role in policy development include climate and hydrology. Cultural factors focus on the two primary values of ranching and wildlife.

\section{Climate}

Malheur Lake Basin climate is arid to semi-arid. Two seasons dominate the weather in the Basin. Winters are long and relatively wet, and summers are short and very dry. Average annual precipitation for the water years ${ }^{1}$ from 1944 to 1990 was 9.87 inches. Both winters and summers tend

1Water years date from October through September; data based on measurements taken at the Malheur National Wildlife Refuge Headquarters climate station. 
to have extremely variable temperatures. Freezing can occur during any time of year. As a closed basin, water exits the Basin almost exclusively through evaporation.

Monthly averages of precipitation for water years 1944 through 1990 indicate that, despite a secondary peak in May and June, most precipitation in the Basin occurs between November and January (Figure 4). Mapping mean annual precipitation isohyets (Figure 5) indicates the effects of topography on the distribution of precipitation across the Basin, with lower elevations averaging less than half the precipitation of high elevations. ${ }^{2}$

Average monthly temperature minimums and maximums demonstrate the ranges of temperature variability (Figure 6), which are not unusual in arid environments, but, combined with a short growing season, make many agricultural activities difficult. The seasonal variation of temperature and precipitation is hydrologically important. Since precipitation in the Basin occurs largely between November and January, about 40 percent falls as snow across the entire Basin, and 65 percent as snow at high elevations (Columbia-North Pacific Technical Staff 1970). The secondary precipitation peak, between May and June, coincides with

2Precipitation and temperature data measured at the Malheur National Wildlife Refuge Headquarters climate station (climate division 07; 43 17" N, 118 50' W; elevation 4,109 feet) are available from 1943. Figures and statistics in this paper are based on these data, from 1943 through 1989 , unless cited otherwise. 


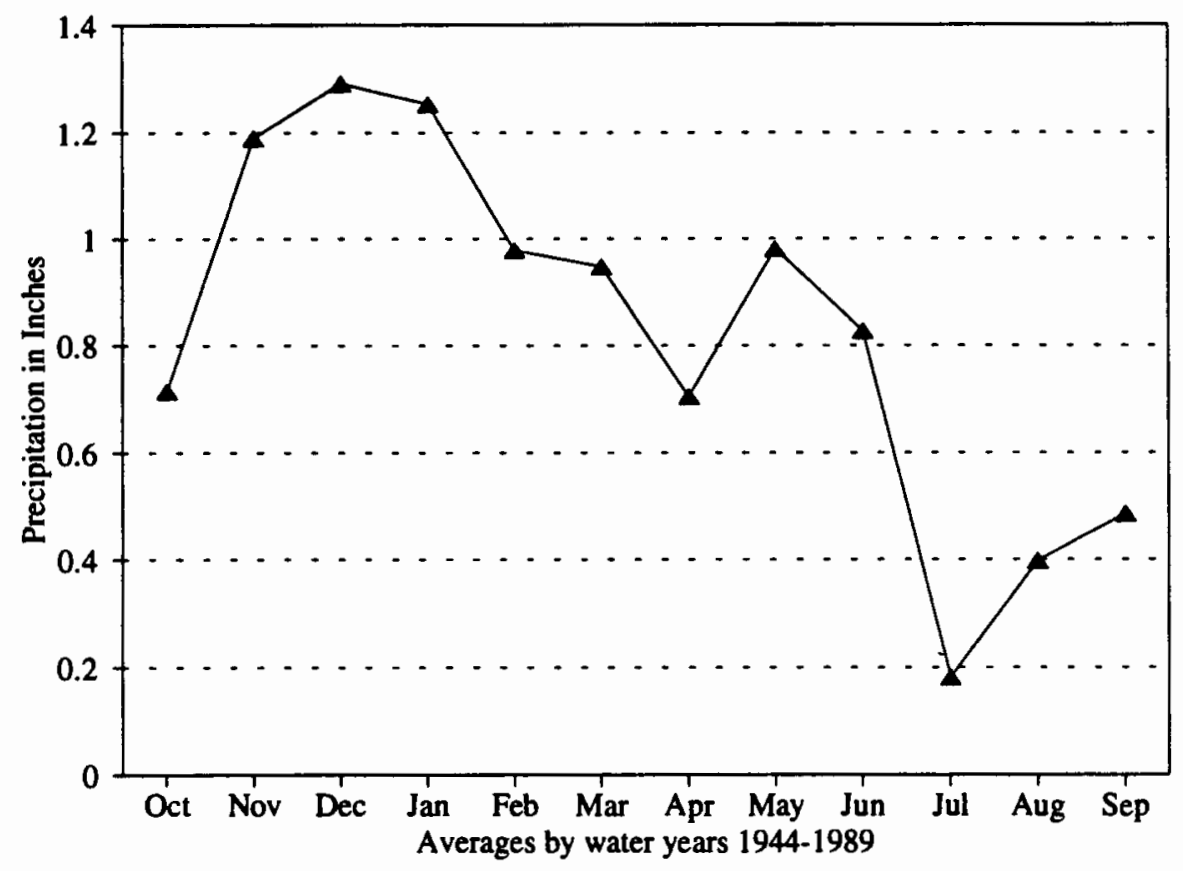

Figure 4. Average monthly precipitation. Based on data from Malheur Climate Station. 


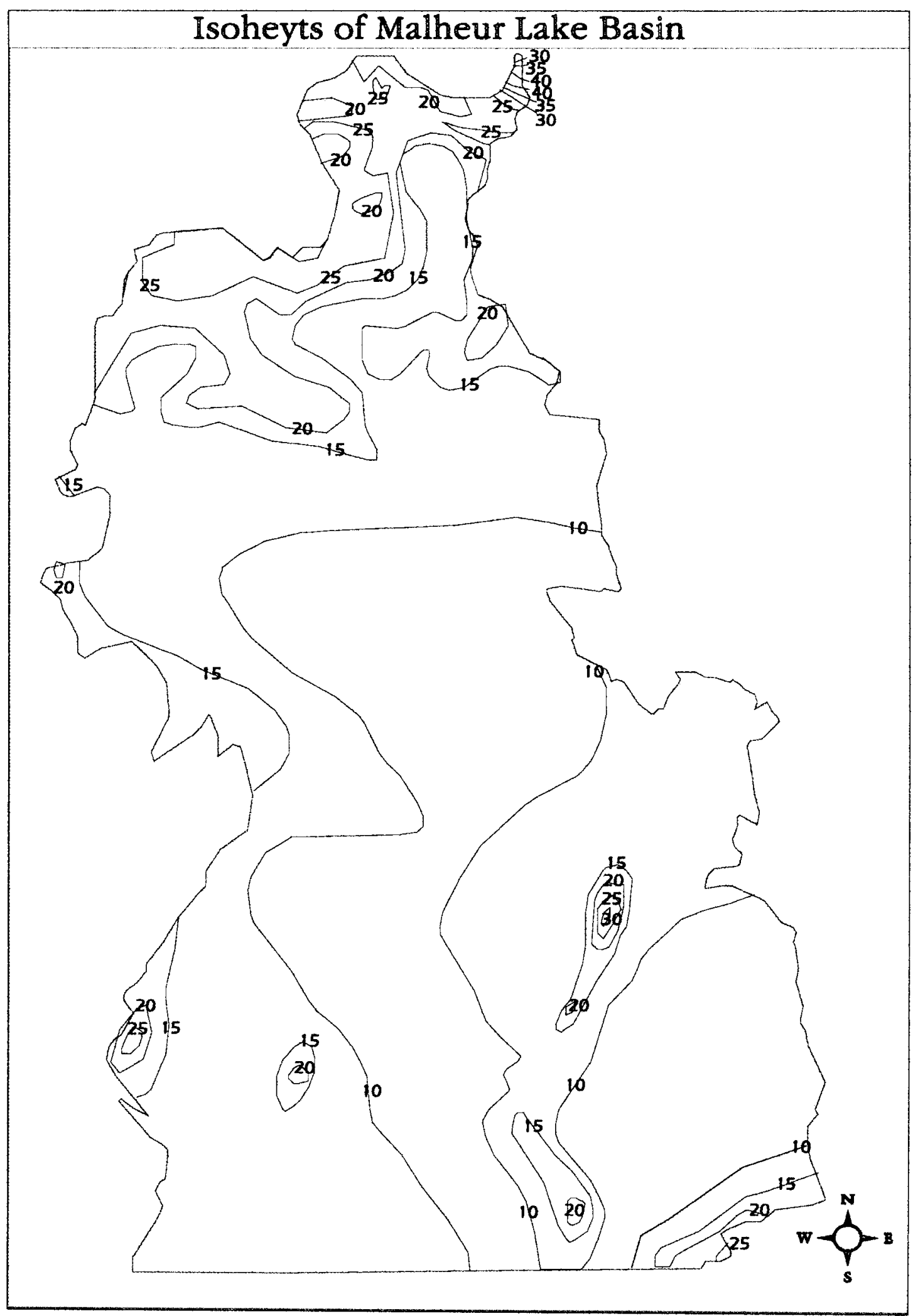

Figure 5. Isohyets of Malheur Lake Basin, Oregon. Average annual precipitation in inches, based on BLM data. 


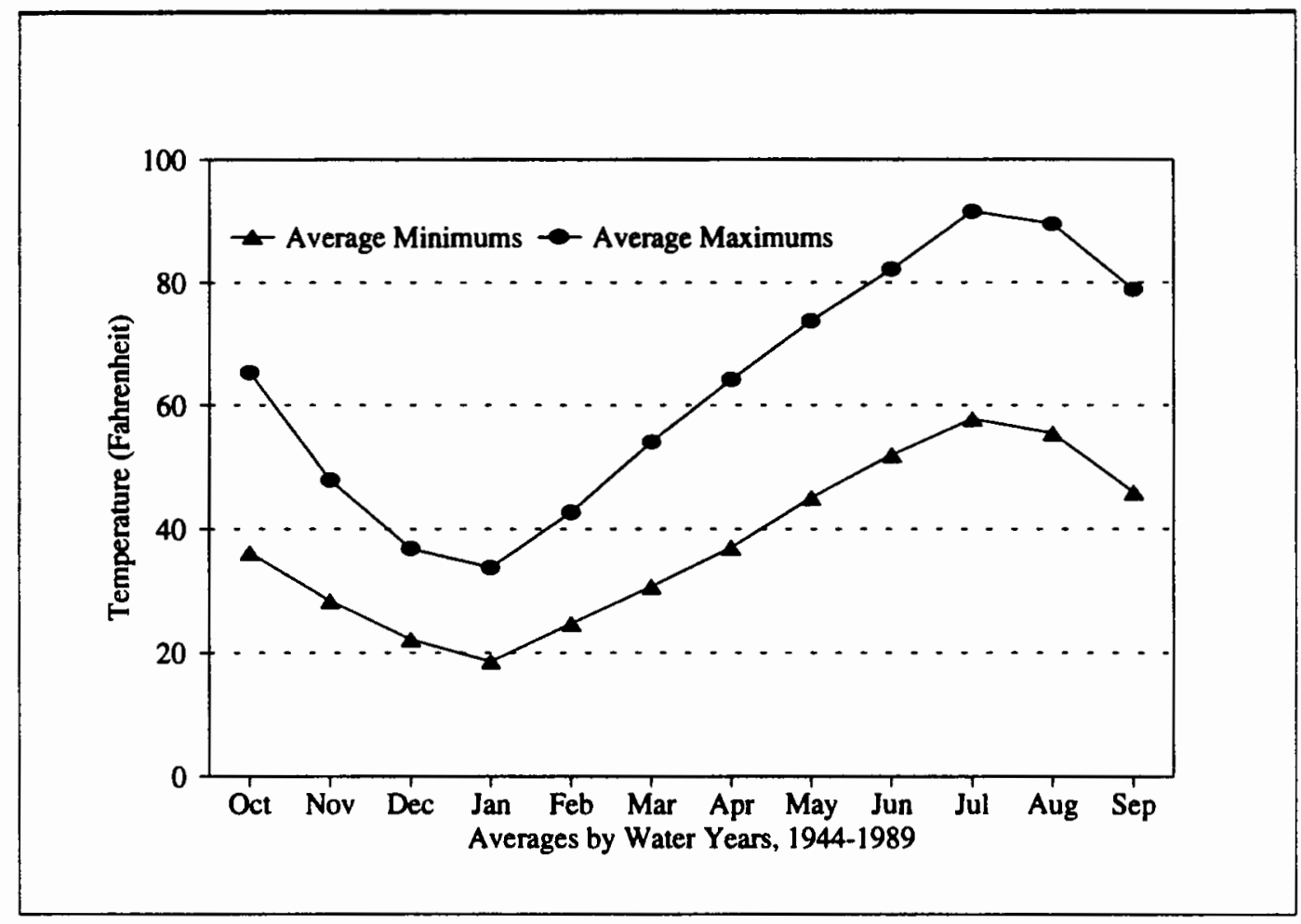

Figure 6. Average monthly temperatures. Based on data from Malheur Climate Station. 
snow-melt. Therefore, most surface run-off and virtually all ground water recharge occurs during the spring thaw (Fuste and McKenzie 1987).

Storage of Basin waters in lakes leads to high levels of evaporation (Rinella and Schuler 1992). Mean annual lake evaporation is estimated to be between 39 and 42 inches (Columbia-North Pacific Technical Staff 1970). Additional significant evaporation occurs from soils in areas where the water table is within 10 feet of the surface, with .5 inches evaporation per day possible where the water table lies within two feet of the ground surface (Columbia-North Pacific Technical Staff 1970).

Other factors affecting evaporation include humidity and irrigation. For example, at Malheur Climate Station average relative humidity in July commonly varies from 50 percent in the early mornings to less than 20 percent in the afternoon. In winter, relative humidity averages 80 to 90 percent at Malheur Climate Station. Evaporation in the summer is considerably higher in summer than it is in winter (Columbia-North Pacific Technical Staff 1970). Flood irrigation of arable land diverts over 100,000 acre-feet each year from Basin rivers to fields (Rinella and Schuler 1992; State Water Resources Board 1967). This flooding coincides with the hottest summer months, exacerbating losses to evaporation (Rinella and Schuler 1992). 


\section{Hydrology}

Basin hydrology factors important to water policy consist of surface and ground water distribution, yields, and water quality. Topography plays a large role in both surface and ground water flow systems, which in turn dictate water distribution and yields. Ground water recharges in upland areas and discharges in the lowlands, along the hydraulic gradient, with a regional flow system generally following topography (Gonthier 1985;

Leonard 1970). With only limited and small scale control structures in the Basin, surface water in the Basin also flows from high elevations to low elevations.

Topography also affects seasonal variations in run-off. For instance, average monthly stream-flow values for the Silvies and Blitzen rivers confirm that the highest run-off occurs between March and June, following the spring snow-melt (Figure 7). Responsiveness of the Blitzen River to runoff lags behind the Silvies River because the Blitzen River drains a smaller area at higher elevations than does the Silvies River. The responsiveness of ground water to changes in climate, both seasonally and long-term, remains to be studied.

Surface Water Distribution. Although perennial streams discharge most run-off in the Basin, the majority of the area of the Basin is drained by intermittent streams into playa lakes. Some intermittent and all perennial 


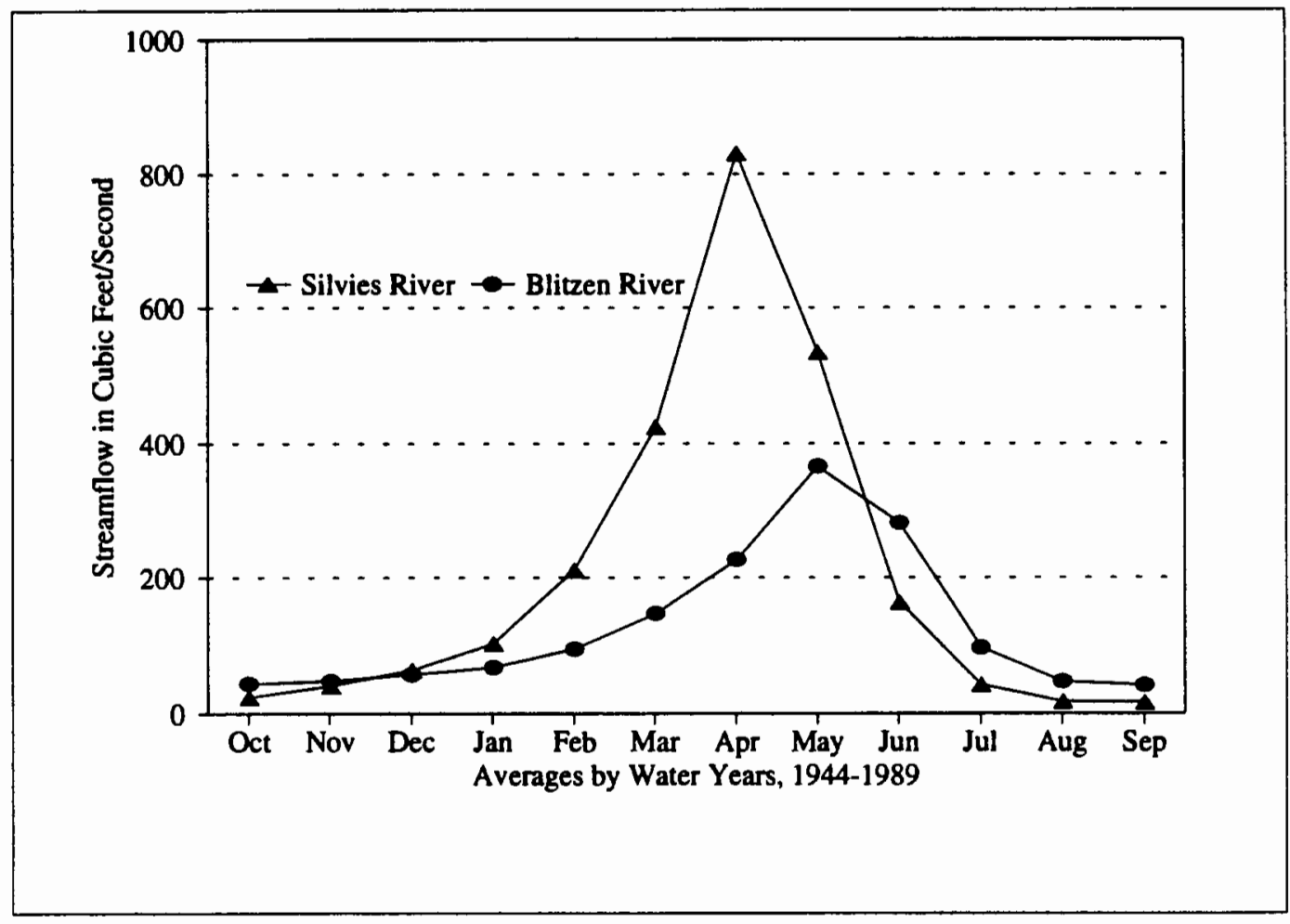

Figure 7. Annual monthly streamflows for the Silvies and Blitzen Rivers. Data for Silvies Rivers from gage 1039500 and for Blitzen River from gage 1039600. 
streams drain into perennial lakes, such as Malheur and Alvord lakes. Measurements regarding the quantity and quality of discharge from intermittent and minor streams are not available. Research and water policy in the Basin emphasizes two perennial streams (Silvies and Blitzen rivers) and the Harney Valley lakes (Malheur, Mud, and Harney).

The Silvies River begins in the Strawberry Mountains and loses about 5,000 feet in elevation on its run to Harney Valley. Because of the volume of discharge, elevation change, and geomorphology, the Silvies River is the likeliest candidate for structural development in the Basin. The Silvies River has the highest yields of the Basin's streams, with an average annual run-off ranging from about 30,000 acre-feet to 220,000 acre-feet over the last 50 years. Silvies River contributes about 25 percent of the total flow into Malheur Lake, which, despite its greater total run-off, is far less than the contribution of the Blitzen River. This is because the majority of water is diverted from Silvies River, for agriculture, before reaching the lake (Hubbard 1975; Fuste and McKenzie 1987).

The Blitzen River originates high on Steens Mountain, draining glacially-carved valleys of the south-central Basin to Malheur Lake. Tributaries include those on the north and west faces of Steens Mountain, from Little Blitzen River to Fish, Krumbo, McCoy, Kiger, and Riddle creeks. One-fourth of the area draining Steens Mountain contributes fifty percent of 
the total discharge of the Blitzen River. This flow peaks primarily in May and June, and continues as snow-pack in high elevation canyons melts during early summer. These relatively late flows usually provide a good irrigation supply throughout the summer, without requiring artificial storage. The Blitzen River has more subdued run-off peaks than the Silvies River (Figure 7). With average annual run-off ranging from about 20,000 acre-feet to about 100,000 acre-feet over the last 50 years, total annual discharge is less than the Silvies River. However, the Blitzen River contributes about 65 percent of the total inflow to Malheur Lake (Hubbard 1975).

Water levels of Malheur Lake fluctuate both with the variations in run-off received and with variations in direct contributions from precipitation. The one percent contribution from ground water, including from Sodhouse spring, is not as variable (Hubbard 1975). Run-off into the lakes averages about 190,000 acre-feet, after consumptive uses. If the lake level exceeds 4,093.5 feet above mean sea level, it overflows into Mud Lake, and ultimately Harney Lake, through the Narrows. Average surface area of all three lakes is approximately 260 square miles. In very dry years, such as 1889,1924 , and 1934, both lake beds, and Mud Lake, are dry. The extremely wet years of the early 1980s increased Malheur Lake levels to a record of 4,102 feet above sea level in 1985 (Fuste and McKenzie 1987). 
Data on the chemical, biological, and sediment composition of streams are limited and available for only scattered sites and times. Based on data available, the water quality of the streams seems to be generally excellent (Columbia-North Pacific Technical Staff 1970; Rinella and Schuller 1992). Phillips and Van Denburgh (1971) questioned the effects of agricultural uses of gypsum (calcium sulfate), for soil conditioning, on surface water quality. Hubbard (1975) found bottom-sediment samples showing minor quantities of pesticides and trace elements. Concern for effects of concentrations, in particular, of arsenic and boron on wildlife led to a USFWS study in $1985-1986$ that showed minimal concentrations of these elements in lake area biota (Rinnella and Schuler 1992). Rinella and Schuler (1992) found that, during 1988-1989, arsenic and boron exceeded Environmental Protection Agency criteria for health protection or for beneficial uses in some lake water and biota samples. However, because these concentrations were not found in all samples it was determined they were not probably causing significant harm.

Of the lakes in the Basin, Malheur has the best water quality (Columbia-North Pacific Technical Staff 1970; Rinnella and Schuler 1992). The lakes generally have much higher total dissolved solids than the streams that enter them (Columbia-North Pacific Technical Staff 1970; Rinnella and Schuler 1992). Fuste and McKenzie (1987) noted that, in 1984 
and 1985, concentrations of dissolved solids increased from Malheur to Mud to Harney lakes. They further observed that dissolved solids in Harney Lake derived from thermal springs near the lake and from evaporation.

Ground water. The Basin's aquifers are believed to be hydraulically inter-connected and highly interactive with surface water systems. Drawdown of ground water supplies is a concern, as this might lower water levels in ponds, lakes, and marshes (Columbia-North Pacific Technical Staff 1970; Rinella and Schuler 1992; State Water Resources Board 1967). Recharge is estimated to be in close balance with discharges to pumping, springs, lakes, irrigated fields (where the water table is shallow), deeprooted plants, and evaporation (Columbia-North Pacific Technical Staff 1970). These factors make development of ground water resources a delicate matter.

Three geologic units in the Basin have primary hydrologic significance as aquifers (Figure 8). A sedimentary unit underlies much of Malheur Lake Basin, with basin-fill and alluvium deposits along existing stream channels, lake beds, and basin floors, to depths of about 250 feet. These sediments include deposits of unconsolidated to semi-consolidated silt to gravel. Underlying that tier are volcanics with interbedded sedimentary deposits, forming the second major unit. These two aquifers outcrop in over half the area of the Basin, and may contain up to 80 percent of the total 


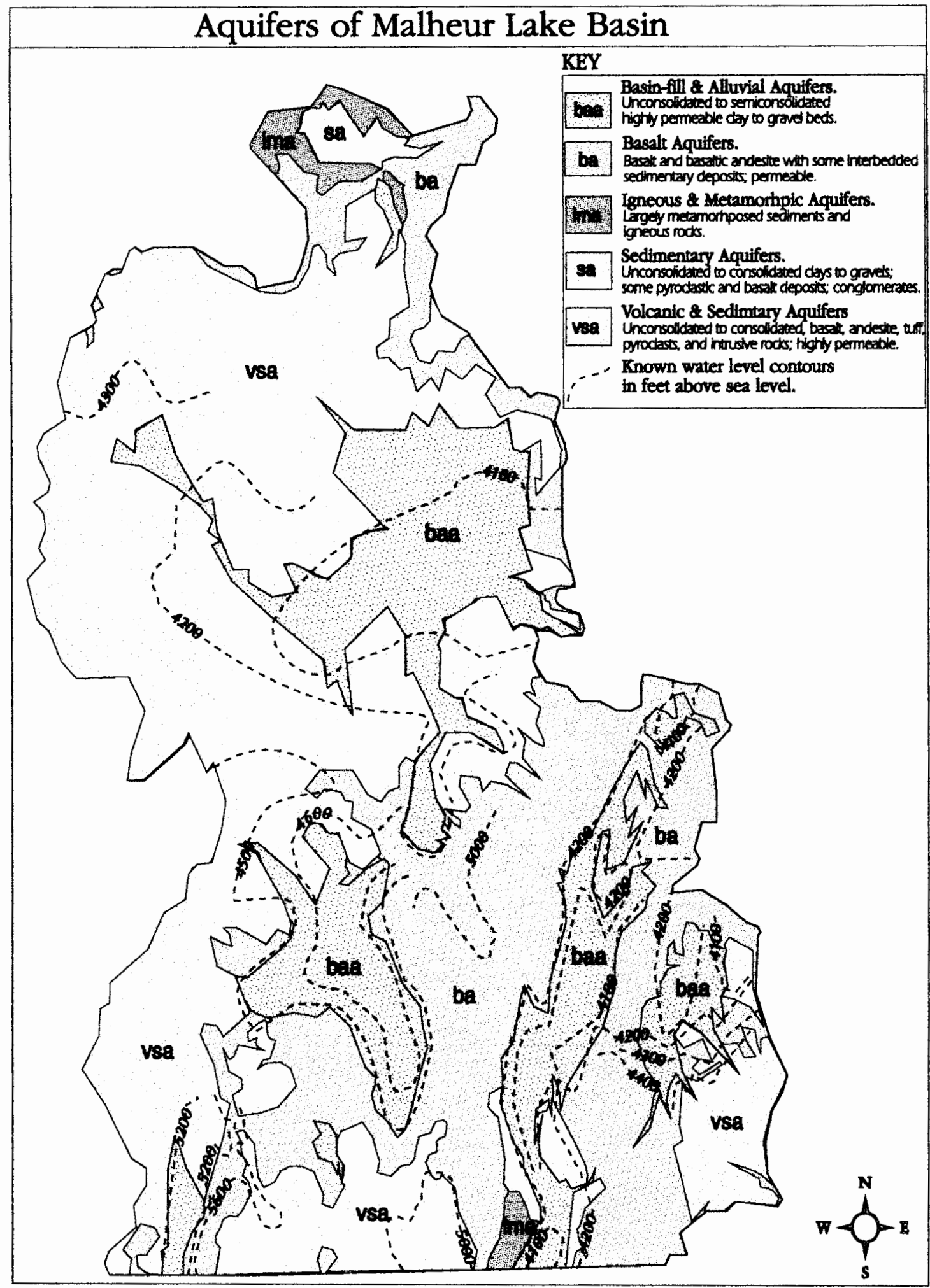

Figure 8. Aquifers of Malheur Lake Basin, Oregon. Known water level contours are shown also. Both based on data available from 1930 to 1980 (Gonthier 1985). 
ground water resources in the Basin. Basalt flows, underlying the second unit, outcrop in the Basin's eastern uplands and comprise the third main unit (Baldwin, et al. 1992; Columbia-North Pacific Technical Staff 1970; Gonthier 1985; Leonard 1970).

Although water quality varies widely from site to site, ground water with under 1,000 milligrams per liter total dissolved solids ${ }^{3}$ is estimated to be between 75 and 80 percent of the total available supply. Basin ground water can have total dissolved solids in excess of 5,000 milligrams per liter (Columbia-North Pacific Technical Staff 19970). Because boron and sodium are toxic to crops, levels of these should be, but are not always, monitored closely in ground water used for irrigation. This applies particularly to areas near lakes, where surface and ground water alike tend to have higher concentrations of dissolved minerals (Columbia-North Pacific Technical Staff 1970; Fuste and McKenzie 1987).

Supply Problems: Shortages and Surpluses. The primary and most common Basin water supply problems are floods and droughts. These result from variable flows seasonally and over years. Flows during the spring season cannot always be used to maximum benefit; inadequate storage facilities mean that the water simply flows to Basin lakes. The late season

${ }^{3}$ Levels recommended by the Environmental Protection Agency are: $500 \mathrm{mg} /$ for drinking water; $700 \mathrm{mg} / \mathrm{l}$ for irrigation; and to $7000 \mathrm{mg} / \mathrm{f}$ for large livestock animals (Freeze and Cherry 1979, pp. 386-388) 
shortages inevitably cause all interested parties concern. For Malheur National Wildlife Refuge, problems include a need for draining certain areas, dividing Malheur Lake into smaller, more attractive habitat units, developing junior water rights in Silver Creek Valley, and managing to cope with the extremely variable water supplies (Army Corps of Engineers, 1957; Bureau of Sport Fisheries 1962; Wallsworth 1995).

Water shortages are common annually in the Basin, during the middle to late summer and early fall. Flooding, to some degree, also occurs commonly, during the spring run-off peaks. This variability of supply challenges Basin water users and managers. Persistence of dry or wet years poses additional problems. Persistent dry periods occurred between 1928 and 1941, 1959 and 1964, and 1987 and 1988; particularly wet years were recorded in 1897, 1952, and between 1981 and 1985 (Paulson, et al. 1991; Fuste and McKenzie 1987; Army Corps of Engineers 1957). Basin residents and officials note that the drought which began in 1987 did not actually end until 1991 (Bentley 1995; Wallsworth 1995).

Floods occur typically between March and May, when snow melts and spring rains fall, but while the ground is often still frozen. Floods primarily affect the more densely populated area around the cities of Burns and Hines. Urban street networks (Figure 9) are particularly vulnerable to floods, and sometimes residents are cut off from access to services. Flood 


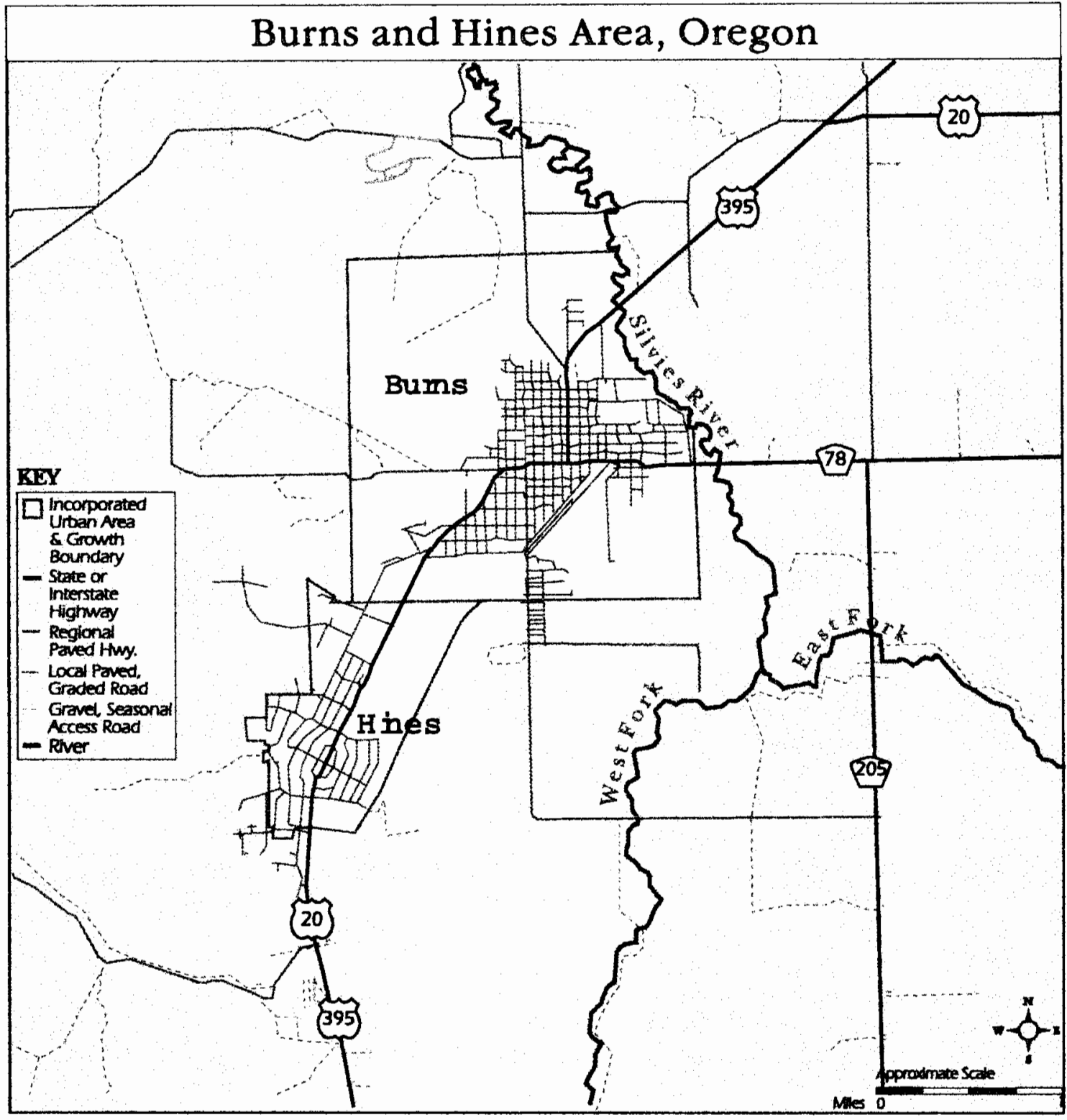

Figure 9. Streets of Burns and Hines, Oregon. Based on BLM data. 
control structures upstream of the urban area on the Silvies River have not been built, primarily because effects on Malheur National Wildlife Refuge are expected to be negative (Wallsworth 1995). Flood waters in the Basin's valleys are used for irrigation when possible, with overflows discharged ultimately to the lakes. About 50,000 acres are flooded annually; most is crop land. Flood irrigation structures have, in some cases, exacerbated problems from flooding. Roads and rail, fields, ranches, residences, and wildlife habitat are damaged when it floods.

The most notable flood on record began with high precipitation levels in 1982 and peaked in 1985 with unprecedented lake levels. On June 27, 1984, Malheur Lake surface elevation reached an historic record high of 4,102.4 feet, where a normal annual maximum is 4,093 feet (Rinella and Schuler 1992, p. 12). At this lake level, more than 170,000 acres were submerged, and Malheur, Mud, and Harney lakes were joined into one lake (Hubbard 1989). Previous lake surface area maximums, between 1903 and 1984, ranged from 50,000 to 60,000 acres (Rinella and Schuler 1992). An average lake surface area of about 46,000 acres is considered normal (State Water Resources Board 1967). Lake elevations increased to 4,102.5 feet in 1985 and to $4,102.6$ feet in 1986 . The drought of the late 1980 s brought on the recession of the lake levels by a foot or more each year to $4,096.4$ in 1990. Parts of two highways, 57,000 acres of wildlife habitat, 25 ranches, 
and the railroad were seriously damaged by flooding (Rinella and Schuler 1992).

\section{HUMAN FACTORS OF WATER POLICY}

Malheur Lake Basin water resources are significant for both agricultural and wildlife-related uses. The local economy has been primarily based on livestock and forest products since European settlement in the late 1800s. This economic base is currently in danger of serious decline in productivity, according to timber and cattle interests. Wildlife and plant habitat throughout the region has been vastly altered by human activities over the last 150 years (Reinhardt 1992). Recognized endangerment of fish, frog, and bird species has led to attempts to better integrate human activities with natural processes to ensure long-term environmental health. Interests in agriculture and wildlife are represented in the local population and also in the federal agencies that own most of the land area in the Basin. The situation is complicated by the tension between state and federal authorities over land and water resources, by private interests in the Basin's environmental quality, and by the international character of the Pacific Flyway of migrating birds. 


\section{Wildlife and Habitat}

Primary wildlife values in the Basin include several large mammals and a wide variety of migratory birds and waterfowl. Key large mammals include pronghorn, California bighorn sheep, and mule deer. Key bird species include the greater sandhill crane, the trumpeter swan, willow flycatcher, and the redhead, mallard, cinnamon teal, and gadwall ducks. Two national wildlife refuges protect populations and habitats of these and other special status species: Hart Mountain Antelope Refuge and Malheur National Wildlife Refuge (Figure 10). Both are administered by the United States Fish and Wildlife Service. Efforts to protect and maintain adequate feeding, breeding, and brooding habitat support the wildlife populations on these preserves. Protected habitats include both uplands and wetlands.

Several types of wetlands habitats are important in the Basin. The submergent and emergent communities of open water areas are critical to bird populations. Sego pondweed, a dominant member of the submergent community, supplies about 80 percent of the diet of all bird species during migration periods. Periodic drying of ponds or lakes stimulates vegetation growth for several subsequent years because this aerates the soil. The alkali playa community includes very little vegetation, except around freshwater springs, where woody shrubs dominate. However, shoreflies hatch in June, providing a food source for shorebirds and waterfowl through the fall. 


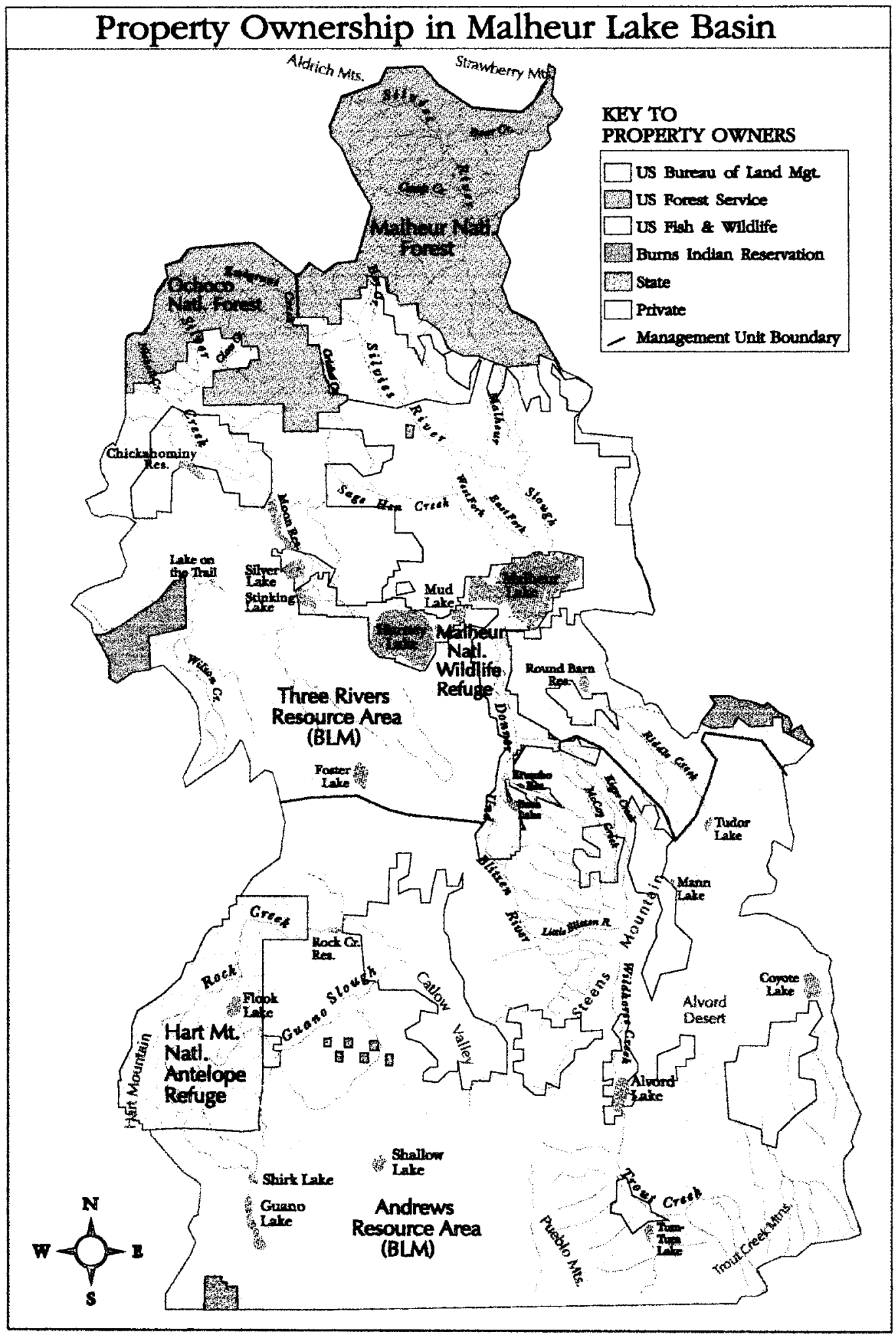

Figure 10. Property ownership in Malheur Lake Basin, Oregon. Approximate property boundaries are based on BLM data. 
Meadows are important producers of grasses, sedges, and thistle. Meadows are the preferred habitat for sandhill cranes, and also certain owls, ducks, and hawks. Along streams and irrigation channels, dense, wooded riparian communities occasionally arise. Some hawks, owls, and northern shrikes prefer these areas (Littlefield 1990).

\section{European Settlement Patterns and History}

European settlement and agricultural activities, in the 1860s and 1870s, displaced the Native American residents and led to the degradation of the native grasslands. A few early cattle-ranching enterprises reaped high profits from the native grasses in the Basin. This livestock boom lasted twenty years, and by the end of the century sagebrush and rabbit brush were rapidly replacing the native grasses (Reinhardt 1992).

The fate of the grassland ecosystem was sealed when as many as three million sheep grazed the Oregon high desert Basin early in the century (Reinhardt 1992). Sheep graze grasses to the roots, ensuring death; cattle, on the other hand, graze to within several inches of the roots. In addition to virtually eradicating the grasses by feeding, grazing livestock intensively degrades stream beds and increases erosion through trampling and disturbance of vegetation and soils. Water quality is degraded by animals defecating near streams. 
Nonetheless, the revised homestead act of 1909 offered 320-acre parcels for $\$ 10$ to promote settlement. Promoters portrayed arable, lush valleys. The settlers instead met with harsh winters, floods, dry summers, unseasonable frosts, and alkali soils. By the mid-1920s, few settlements remained, and many homesteads had reverted to the government (Reinhardt 1992). Roughly the same settlement patterns of the 1900s persists today. Single-family ranches are thinly scattered throughout the Basin, and most of the Basin's population of about 6,000 reside in Harney Valley. Harney County grew from 2,559 to 4,059 residents between 1890 and 1910, and to a peak of 8,314 in 1980 . However, between 1980 and 1990 the population in Harney County declined to 7,060 (U. S. Department of Commerce 1913a; 1922b; 1993a). Agricultural activities, including ranching, in the Basin have been fairly static for almost a century. In 1910, there were 443 farms in Harney County; in 1992, there were 442 (U. S. Census Bureau, 1913b; 1993b). In 1992, about 22 percent of these farms grossed over $\$ 100,000 ; 19$ percent grossed under $\$ 2,500$. The remaining 59 percent make sales amounting to between $\$ 2,500$ and $\$ 100,000$ annually (U. S. Census Bureau, 1993b).

Conservation efforts were not altogether absent during the period of settlement by Europeans. Malheur National Wildlife Refuge was established in 1908 by the executive order of President Theodore Roosevelt 
as a bird sanctuary. In 1935 and 1941 over 120,000 acres of additional land was annexed from two area ranches, bringing the total area under refuge authority to over 184,000 acres. Water rights were acquired with the land annexations (Rinella and Schuler 1992; U. S. Fish and Wildlife Service 1992). Hart Mountain National Antelope Refuge was established in 1936. The total area within the refuge boundaries is 277,893 acres. This includes 11,998 acres of state in-holdings, and 14,600 acres of private and county inholdings (U. S. Fish and Wildlife Service 1994). The Taylor Grazing Act (1934) established a permit system for grazing that curtailed unlimited grazing by sheep. As the sheep disappeared from the range, certain native flora began to reappear (Reinhardt 1992). Under the Wilderness Act of 1964 , millions of acres were recently reserved as potential wilderness areas ("wilderness study areas"). This prevents logging and development of infrastructure (roads, power lines) on these lands, though some grazing and mining are allowed to continue (Reinhardt 1992; U. S. Bureau of Land Management 1993a).

Efforts by livestock interests to rehabilitate the depleted rangelands have included fencing streams, removing sagebrush and juniper, and seeding with wheatgrasses. Modifying vegetation fosters problems including encouraging erosion, opening ground to invasion, and limiting habitat diversity (Benyus 1989). These endeavors occur on both private and public 
lands, with guidance and assistance from the BLM (U. S. Bureau of Land Management 1982; 1992b).

\section{Governance and Policy Planning}

In 1967, Oregon determined that no water remained under state jurisdiction in the Basin, as supplies were over-appropriated (State Water Resources Board 1967). No state plan for the Basin water resources has been released since that 1967 report, which advocated structural development for flood control and supply storage. The most recent relevant federal agency plans were drafted and approved within the last five years. Rather than restricting natural variability, these plans seek to manage through simulation of the natural patterns of a variable water supply.

Such mimicry is still a method of control, however. Radical changes in land use, such as condemning or retiring the farm or rangeland, are not considered; even slight decreases in grazing allotments on National Wildlife Refuge land lead to public outcry. The human struggle to carve a living out of this Basin's uplands and wetlands continues, mostly through agriculture (Figure 11), but occasionally, and increasingly, through tourism.

State Water Policy. Oregon has a history marked by increasing emphasis on regional administration of water resources. In 1864 , the state legislated that miners could claim water rights (Oregon Water Resources 


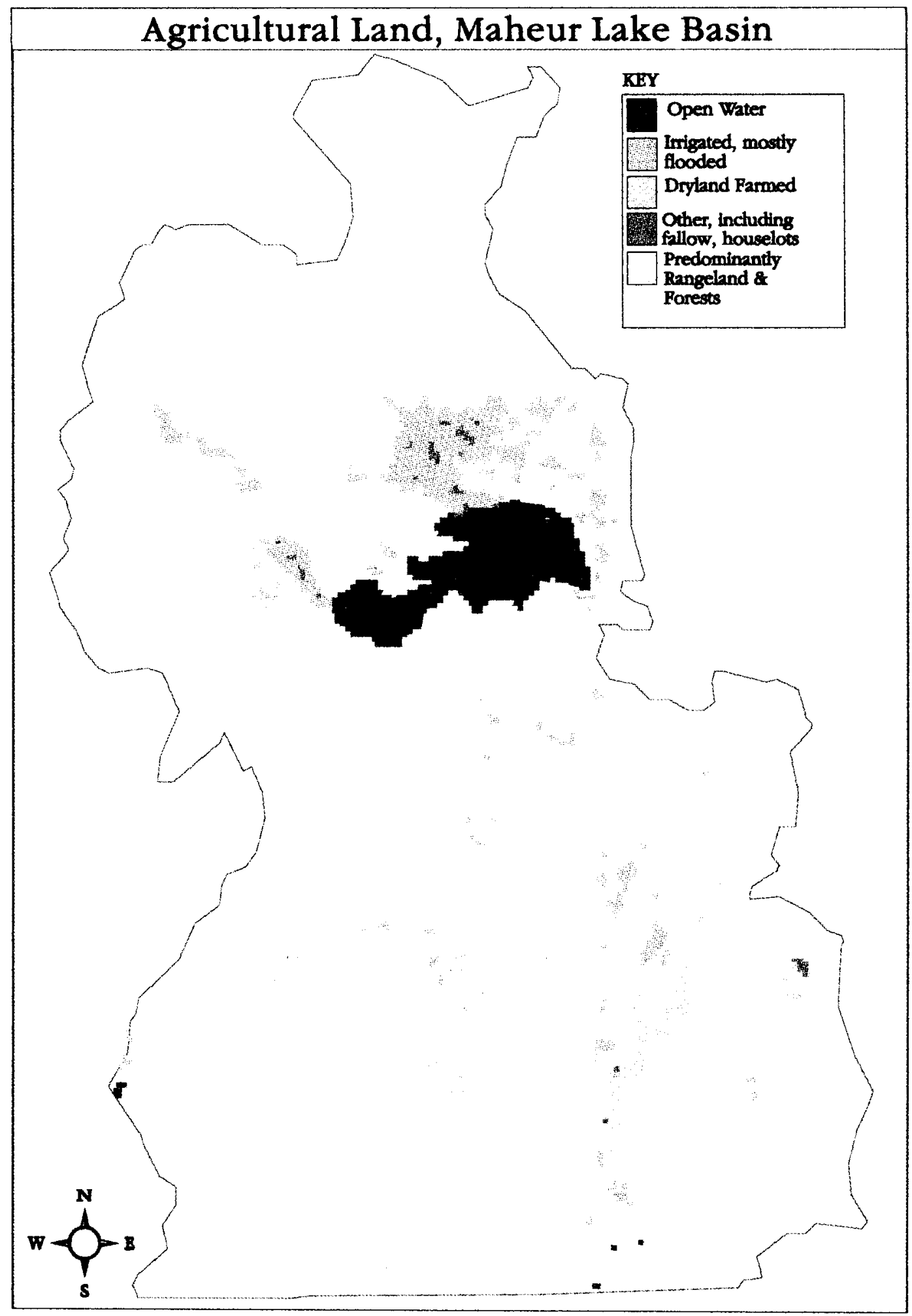

Figure 11. Agricultural land in Malheur Lake Basin, Oregon. By irrigation class, based on BLM data. 
Department 1992). In 1868, the legislature provided that landowners might apply for county permits for draining wetlands, modifying stream channels, and constructing flood control embankments. In 1891, the state defined the first beneficial uses as irrigation, livestock, and domestic uses. Mining and hydropower were added in 1899 to this list. The control of the state over waters within its borders was formalized in the Water Appropriation Act of 1909, often called the State Water Code. In 1955, the State Water Resources Board was created, which merged with the State Engineer's Office to form the existing Water Resources Department. In 1985, restructuring placed the new Water Resources Commission in charge of the Water Resources Department.

Oregon's water law system is based on rights of prior appropriation and also elements of riparian law, as codified in the Water Appropriation Act of 1909. Water rights in this system are property rights. A water right is dated, for priority, with the date the right was claimed. The right specifies how much water, from what source (or diversion point), will be applied where, for what purpose. The purposes must be beneficial uses. The right is forfeited if it is not used at least once every five years. If water is in short supply or over-appropriated, rights with the oldest dates are honored first. Any water right can be transferred, if properly sought and authorized through the Water Resources Department. 
Some surface and ground water uses are exempt from usual water rights. For example, land owners may use spring water that originates on their property and does not form into a channel that flows off their property. Stock watering is also exempt, as long as surface water is not diverted for this use. Watering of non-commercial lawns and gardens of less than onehalf acre with ground water is exempt. Industrial and commercial use of ground water is exempt if for a single purpose and not in excess of 5,000 gallons per day (Oregon Water Resources Department 1994).

In the 1967 Malheur Lake Basin Report, the state proposed a comprehensive water resources policy and plan for the Basin. This plan, still theoretically in effect, suggests that economic growth and concurrent maintenance of wildlife goals are possible in the Basin. In order to strike a better balance between these apparently competing goals, the plan proposes construction of a dam and reservoir in the Silvies Canyon. The state and the Army Corps of Engineers have both recommended developing the Silvies River (Army Corps of Engineers 1957; State Water Resources Board 1967). As noted previously, such development has not been undertaken. This is apparently because of the uncertain effects on habitat for birds visiting and residing on the Malheur National Wildlife Refuge (Wallsworth 1995).

The state recently developed a new drought policy. Because of a statewide drought in the late 1980s, Oregon's governor appointed an interagency 
Drought Council, which began comprehensive planning for future droughts. The Drought Council is inventorying resources available to respond to drought conditions and developing plans and procedures to mitigate the effects of drought. Perhaps most importantly for Malheur Lake Basin, this council has drafted procedures for simplifying legal water rights transfers under drought conditions.

Drought becomes official when the governor declares an area to be a drought emergency area. The governor is prompted to make such declarations on the request of a county. Counties typically make requests when the U. S. Natural Resource Conservation Service releases its streamflow forecasts based on the snow-pack. By law, during droughts, junior water rights holders would forfeit any rights to available water while senior right holders receive their full allotment. However, one method used in the Basin to manage dry years is temporarily transferring water rights. In the past, this required applications for special permits and waivers from the Oregon Water Resources Department. Since many counties are concurrently affected by drought, this created excessive paperwork for the Water Resources Department. The new procedures establish means of easily and legally transferring water rights when drought conditions are declared, thereby mitigating the impacts of drought (Norris 1994). 
Federal Water Policy. Federal agencies (the BLM, the USFS, and the USFWS) hold most of the land in the Basin (Figure 11). These agencies manage the water under their jurisdiction in accordance with their missions and land-use objectives, and include water management plans in policies, land use plans, and environmental impact statements. These plans each typically consider several alternatives, generally in comparison with both a preferred alternative and a projection of baseline, existing plans. Local participation is encouraged through a public review process. While policies are typically set to correspond to national goals and agency missions, policy makers adjust plans in the review process to accommodate public objections that do not compromise agency missions. The final decision to implement plans is made by the particular agency's district officials, with regional office approval.

The USFS has the least visible and least controversial role of the three federal agencies in the Basin. In the northern Basin, 779,400 acres fall under USFS jurisdiction. Responsible for the lands that provide headwaters for the Silvies and Silver rivers systems, the USFS manages the Malheur and Ochocco National Forests for multiple uses, including timber harvests, grazing, recreation, and wilderness preservation. Plans are subject to review every 10 years. The current plan for Malheur National Forest was implemented in 1990 , and the current plan for Ochocco National 
Forest was implemented in 1989. These plans anticipate few changes in land and water use and management over the next ten to twenty years (U. S. Forest Service 1991).

The BLM is responsible for the multiple use development of public lands and resources, and also for providing sustained yields and enhanced environmental quality (U. S. Bureau of Land Management 1986; 1992b). The BLM Burns District contains two management areas, both of which fall primarily within the Basin. The southern boundary of the Three River Resource Area lies about 20 miles south of Malheur and Harney lakes, and extends north beyond the Basin boundary. The BLM lands south of this management area, as far as the Oregon border, are included in the Andrews Resource Area. Most BLM lands in the Basin are rangelands. The rangelands are managed within a system of grazing allotments for consistent levels of grazing over time and for rangeland improvements. Programs for rangeland improvements include riparian rehabilitation projects and various rangeland vegetation improvement projects (U.S. Bureau of Land Management 1986; Bentley 1995).

The BLM also manages specially designated areas. The Wilderness Study Areas ("WSAs"), maintained for the time being as though already designated, were first proposed in 1985. In the Basin, 21 of 23 proposed WSAs, covering a total of 1,075,337 acres, lie in the Andrews Resource Area 
(U. S. Bureau of Land Management 1993a). Two other areas have special designations. First, part of the Blitzen River and several tributaries, a total of 74.8 miles of streams, became a National Wild and Scenic River in 1988. Second, the Steens Mountain loop road, built beginning in 1930 and completed in 1962, was to close in 1982 . Because of opposition and continued public use of the loop road area, this closure was never implemented. In spite of protests appealing the continued use of the loop road, filed by the Oregon Natural Resources Council, funds for improving the loop road area were approved in the spring of 1995 (Bentley 1995).

Although the USFWS has an established national mission, the two refuges in the Basin are managed somewhat differently. The national mission, in brief, is to preserve, enhance, and restore ecosystems for all endangered or threatened species, and to preserve migratory bird populations (U. S. Fish and Wildlife Service 1982). However, the two refuges have distinctly different physical landscapes and different specific goals. Malheur National Wildlife Refuge, located in wetlands, emphasizes protection of migratory and endangered bird populations. Hart Mountain National Antelope Refuge, sited on a ridge, emphasizes protection of native and endangered large mammals.

The management goals of the USFWS for Malheur National Wildlife Refuge ("Refuge") are more single-purpose and visible than those of other 
agencies in the Basin. The Refuge mission stipulates maintenance of habitat diversity, wildlife diversity, public use quality, and wildlife quality. The principles set forth to guide management practices include an emphasis on holistic, ecosystems approaches, native/indigenous species, and natural processes, such as drought-flood cycles, fire cycles, and grazing (U. S. Fish and Wildlife Service 1985). Under drought conditions, the priority for water uses is pond maintenance; during floods, the priority is to maximize water use, while at the same time preserving emergent plant communities (Wallsworth 1995).

Two areas in the Refuge allow for structural and developed management of water with dikes, ditches, water-control structures, constructed ponds and nesting islands, farming, grazing, and irrigation. The area surrounding and including Harney, Mud, and Malheur lakes is managed to closely simulate natural hydrologic processes (U. S. Fish and Wildlife Service 1985; 1992). In recent years, adjustments to plans have been made to still more closely reflect natural processes, even in the structurally managed areas (U. S. Fish and Wildlife Service 1994). Changes to existing practices in the Blitzen Valley, for example, include decreasing grazing permits by nine percent, and doubling hayfields (U. S. Fish and Wildlife Service 1990). 
Hart Mountain National Antelope Refuge ("NAR") was established by executive order in 1936 and contains a total of 277,893 acres. All but the steep west slopes of Hart Mountain and Poker Jim Ridge are contained within Malheur Lake Basin. The current management plan, developed between 1989 and 1994, will be in force through 1999. The goals of the Refuge include management for healthy pronghorn populations, restoration of native ecosystems, and primitive recreation and education (U. S. Fish and Wildlife Service 1994). In particular, restoration of riparian habitats and eroded stream channels, and overall watershed stability, is of high priority. The degradation of riparian habitats is attributed to severe, persistent overgrazing. Complete habitat restoration is expected to take 200 years. The issue of livestock grazing on NAR lands continues to be controversial, as it is throughout the Basin.

\section{Interagency and Intergovernmental Conflicts}

The most obvious source of friction lies between those who represent the interests in water and land use for agriculture on one hand and for wildlife habitat on the other. Both rely on water and conflicts over water arise particularly during shortages. The most apparent tension exists between the BLM and the USFWS. Though representatives of both agencies acknowledge some tension, and the need for improved relations, rarely are 
members of one agency included in development of plans and policies. For instance, though one of the BLM's goals is to increase consultations with the USFWS (U. S. Bureau of Land Management 1986), the USFWS was not consulted in the preparation of the National Wild and Scenic River Donner and Blitzen Management Plan (1992). Other agencies were consulted including the USFS. This is in spite of the fact that the USFS lands lie over forty miles to the north, while the Malheur National Wildlife Refuge includes lands downstream of the designated Wild and Scenic River area. Further, the BLM is subject to the conditions of the Endangered Species Act of 1973 and has both Wildlife Management and Endangered Species Management programs. Explicit mention is made of coordinating these programs closely with the Oregon State Department of Fish and Wildlife; no mention is made of the USFWS (U. S. Bureau of Land Management 1986). Although the intent of the BLM programs parallels the intent of the USFWS mission, it is as though the programs are competitive rather than complementary.

Conflicts have also come up between Oregon and the USFWS over Malheur National Wildlife Refuge. Following the establishment of the Refuge, the state argued that "it had legal jurisdiction over those lands within the meander line of all navigable bodies of water within the State, including Malheur, Harney, and Mud lakes" (USFWS 1985, p. 18). The 
State was found not to have such a title to those lands in the mid-1930s, upholding the federal designation of the Refuge lands.

During the 1950s, Oregon challenged the use of Refuge water rights for wildlife habitat preservation. The water rights in question were acquired with the ranch property annexations to the Refuge. Water rights in Oregon are permitted for uses specified at the time of the claim. The State alleged that the USFWS was not using the water for the uses stipulated in the right. However, the USFWS was determined in court to be using the water appropriately and the water right was upheld, rather than reverted to the state (U. S. Bureau of Sport Fisheries 1962; Wallsworth 1995). Notably, both conflicts between Oregon and the USFWS and between the BLM and USFWS occur where one jurisdiction is geographically virtually surrounded the other. Conflicts with private organizations and interests tends, on the other hand, to occur when plans and policies are revised.

The opposition of environmentalists to the preliminary testing for geothermal energy development at Borax Lake by Anadarko Petrochemical is an example of private parties' resistance to changes in water policy. Groups including the Oregon Natural Resources Council and Nature Conservancy were involved in protesting the plant on the grounds that it may endanger the rare Borax Lake Chub, a carp (Cockle 1994). 
Another example is the resistance of ranchers to changes in grazing allotments and waterhole access in recent years. For instance, one rancher's grazing permit for a Malheur National Wildlife Refuge allotment and waterhole access was rescinded by the USFWS two years ago. The rancher grazed and watered livestock on Refuge lands without the permit and was arrested in August of 1994. The USFWS had decreased grazing permits on Refuge lands over the previous several years, heedless of the objections of the ranching community. BLM rangeland policies had also changed in recent years. The arrest served as a catalyst for the dissatisfaction of the ranchers with federal policies, and a large demonstration was organized in support of the arrested rancher and in protest of changing federal policy (Hogan 1994).

These conflicts have led to trade-offs and compromises in policy. The agricultural and economic development interests have won some conflicts. The idea of competitive bidding for state grazing permits was never made into policy (Barnard 1994). BLM rangeland management and grazing policies have been reformed over the last decade to include wildlife, wilderness, and rangeland habitat protections. However, national rangeland reforms proposed in 1994 that included greatly increased grazing fees, among other stipulations, were largely successfully resisted by ranching interests (Durbin 1994). The BLM was upheld in its development of the 
Steens Mountain Loop Road recreation area (U. S. Bureau of Land Management 1993b). Anadarko Petroleum will certainly be developing a geothermal plant near Borax Lake in the Alvord Desert, though the Nature Conservancy bought the 10 acre lake (Cockle 1994).

The wildlife habitat preservation interests have prevailed in other conflicts. There has been no major structural development of Basin rivers, though this would be supported by many ranchers (Bentley 1995). There is an increasing emphasis on wildlife protection and habitat improvement, including rangeland improvement, by all agencies holding land in the Basin (U. S. Bureau of Land Management 1992b; U. S. Fish and Wildlife Service 1990). The relatively senior water rights of the Refuge have been upheld, which is significant because Refuge lakes collect much of the run-off of the Basin Wallsworth 1995). This means that negative impacts to Refuge water must be considered by upstream water and land users. The authority of the federal government over federal lands, established by the U. S. Constitution Property Clause, has been upheld, allowing federal agencies to set locally unpopular policy in order to fulfill their missions (Durbin 1994; Anonymous 1995). Although conflicts over water and related land use policy may occasionally be severe, they seem to lead ultimately to policy trade-offs and compromises. 


\title{
CHAPTER IV
}

\begin{abstract}
ANALYSIS
This comparison evaluates each of the models to determine if they provide useful frameworks for Malheur Lake Basin water policy. The assumptions of both models are shown to be overly-simplistic and unrealistic in comparison to Malheur Lake Basin circumstances. Further, the objectives and methods each proposes to address their assumptions are not useful for Malheur Lake Basin water policy. Because some objectives and methods are no different from the existing system, replacing the existing system with them in order to improve water policy makes little sense. Other objectives and methods are simply not feasible for application in the Basin. Finally, both models omit consideration of critical factors for Basin water policy.
\end{abstract}

In particular, four areas are found to be discontinuous between the models and the case (Figure 12). Feldman believes that water is not a commodity and the capitalist markets are not the best basis for making policy decision. Further, he considers participation in water policy processes to be limited to narrow interests. The solution he proposes in 


\section{FELDMAN}

Water is not a commodity

Capitalism \& markets are not good engines for water policy decisions

Participation in water policy is too limited

Seeks a top-down approach: normative environmental ethic and social contract rules for decision-making to guide watershed administrations

\section{ROGERS}

Water is a commodity

Capitalist markets are good engines for policy (if regulated)

Too many participants in water policy processes

Seeks top-down approach: centralized, federal authority regulating water market transactions and problem-shed administrations

\section{MALHEUR LAKE BASIN}

Water supplies are naturally variable

Two strong, persistent, sometimes conflicting priorities for water Number of participants not as important an issue as the identity of participants

Local resistance to federal authority, but reliance on access to federal lands

Figure 12. Comparison of two water policy models and Malheur Lake Basin, Oregon. 
his model is a top-down approach, with principles of a normative environmental ethic and rules of a national social contract providing the basis for water policy development.

Rogers believes that water is a commodity and that increasing privatization and market strategies will lead to improved water policy. Rogers considers the number of participants in water policy development to be excessive. The model he suggests also offers a top-down strategy, with a centralized, federal authority regulating water market transactions.

The circumstances surrounding water policy in Malheur Lake Basin are significantly different than those in the models. Water supplies in the Basin are naturally widely variable. Two strong priorities for water use have persisted in the Basin since European settlement. These priorities relate to the two primary Basin lands uses for agriculture, largely ranching, and for wildlife habitat. The agricultural priority is driven largely be economic concerns and the wildlife priority is motivated largely by environmental concerns. However, there is no evidence that environmentalism and capitalism are mutually exclusive priorities in the Basin. The level of participation in the Basin by private parties is high and both federal and state agents are also represented in Basin policy development. Although the number of participants in water and related land use policy is sometimes high, the identity and affiliation of participants 
with one of the two primary interests seems to be more important than the number of participants. Finally, there is strong local reliance on public lands for both ranching and wildlife, with a concurrent, and increasing, resistance to federal authority.

For instance, numerous individuals and organizations with an interest in ranching, and fewer with environmental concerns, attended local meetings, one with Secretary of the Interior Babbitt, over recent reforms of federal rangeland policies (Durbin 1994). Resistance to raised grazing fees by ranchers throughout the West, similar to the resistance evidenced in the Burns meetings, effectively blocked a drastic increase in the fees. An acceptable policy decision was made with numerous participants. This example also illustrates local resistance to federal authority.

Alternately, the establishment and maintenance of Malheur National Wildlife Refuge and water rights has been disputed by the state and also by local individuals such as the rancher who was arrested in 1994. Yet, the rights and decisions of the Refuge have been upheld effectively, with water policy decisions made by a single participant. First President Roosevelt established the Refuge by executive order, and subsequently most on-going decisions are made by the USFWS solely. These decisions have required support of the courts on occasion, for instance when the state challenged the 
Refuge's rightful use of water allocations in the $1950 \mathrm{~s}$. Nonetheless, water policy decisions have not led to frequent and obvious local resistance.

\section{FELDMAN'S MODEL AND MALHEUR LAKE BASIN}

Feldman believes that good water policy decisions are not based on the market and that focusing on economic considerations in water policy precludes the consideration of non-economic values. He recommends replacing capitalism with environmentalism, and increasing pluralism in water administration by establishing a new regional system. However, Basin circumstances show that market-based decisions have not necessarily had bad outcomes for either people or their environment. Further, capitalism and environmentalism are not necessarily mutually exclusive in the Basin. Finally, establishing a new regional system instead of the existing state system of water law is not feasible.

\section{Economics}

In the Basin, the history of water rights appropriations determines water allocations. This system of water rights originally developed to accommodate miners' pre-existing method of making water rights claims. It served, as intended, to encourage settlement and economic growth in the state. However, this is no longer the case. Because water in the Basin is 
over-appropriated, it is possible that economic growth is functionally constrained. While the population and agricultural statistics vary somewhat over time, they nonetheless suggest that economic growth in the Basin is limited.

Feldman does not model concrete strategies for assessing noneconomic values in making policy decisions in spite of his focus on such values. In the Basin, non-economic values are considered and debated widely. Ranchers are involved in rangeland improvements (Bentley 1995; Bureau of Land Management 1986; Otley 1994). Ranchers have no interest in worsening the already difficult conditions in the Basin. Many ranchers deny that grazing degrades land and water resources and believe that wellmanaged grazing contributes to the overall environmental health of the Basin.

Non-economic values were a factor in establishing the wildlife refuges and other protected areas in the Basin. It is difficult to imagine that revenues generated by visitors to the refuges were ever expected to be sufficient to be a primary motivation for the designation of large portions of public lands as protected areas. Although the actual motivations may have been partially political, rather than strictly environmental, nonetheless such motives led to serious and continuing consideration of non-economic values in the Basin. Non-economic values held by residents and visitors 
alike include a sense of place, scenic views, and proximity to nature, wildlife, and wilderness (Otley 1994; Wallsworth 1995; Bentley 1995).

Feldman fails to consider certain factors critical to Basin water policy. Humans must, according to Feldman, live in harmony with nature and accept nature's uncertainty. This does not account for people's practical need for forecasting productivity levels, and does not provide for concrete measures to prevent or compensate for losses from unexpected events. In the Basin, forecasting availability of water each year can be literally a matter of survival for some residents.

Law

One of Feldman's primary concerns is that water rights do not balance water supply with demand. Also, water rights transfers, claims Feldman, are not feasible under existing systems of law. Water rights in the Basin indeed are not based on physical availability of water. A water right allocates a specific amount of water for a certain purpose at a certain time, rather than a percentage of available water for the best use given that year's supply. However, some forecasting of water supplies is done by the U. S. Natural Resource Conservation Service. While this does not have direct implications for water rights (i. e., water rights are not affected by the 
predictions) such forecasting does allow users to modify their plans for that year or to apply for water transfer permits.

Feldman claims that existing water law systems do not allow for water rights transfers; this is not the case in the Basin. Water rights transfer rules are being revised to allow for simple processing of predetermined transfers during times of shortages. These were always permissible with an approved application to the State Water Resources Department (Norris 1994; Bentley 1995).

Feldman also alleges that ground water is not treated adequately under water law. However, Oregon water law has permitting rules for ground water similar to those for surface water. Other than certain exempt uses, such as domestic use, permits for use, as well as for digging wells and holes, are required. Further, the expense of developing wells in much of the Basin, for instance where the water table is at great depth, is a factor that limits exploitation of this resource.

\section{$\underline{\text { Politics }}$}

Feldman suggests replacing the existing system of state water laws with a regional system of water policy administration to facilitate the replacement of capitalism with environmentalism. Such a system might resolve certain jurisdictional overlaps in the Basin, but the circumstances of 
the Basin do not uphold the idea that it is necessary to replace capitalism with environmentalism. Environmental concerns are not necessarily excluded from consideration in policy in spite of a capitalist economics system. Non-economic, environmental values are considered seriously in Basin policy and planning, as are economic values.

A main political concern of Feldman's is that all public interests are well-represented in the political process. Interests that exist internally to the Basin are well represented politically, and external interests also have participated in local politics. Basin policy development is directly concerned with balancing these interests, such as local ranching interests and national and local interests in migratory bird protection. Those interests that are not directly involved in governance are represented through private participation in political processes, through committees, groups, and as concerned citizens and individuals. Citizen committees have been set up to advise both the USFWS and the BLM in developing plans and environmental assessments. Private, non-profit organizations particularly active in local policy development include the Oregon Cattlemen's Association, Oregon Natural Desert Association, Oregon Natural Resources Coucil, Oregon Trout, Oregon Watershed Improvement Coalition, the Nature Conservancy, and the Sierra Club. Although there are often conflicts 
between interest groups, particularly over water and land use issues, these have historically proved to lead to trade-offs and compromises.

\section{Objectives and Methods}

Feldman's primary objectives are developing harmony between society and nature and establishing an environmental ethic that provides for equitable distribution of resources. This objective is largely irrelevant as a water policy goal for the Basin. Ranchers and wildlife preservationists alike enjoy the natural values of the Basin landscape. However, the belief that human society will exist in complete harmony with nature is naive and unrealistic. Natural variability in water supplies and climate do not encourage consistently harmonious relations between humans and their environment in the Basin. Instead, as balances between various human interests are wrought often as naught through conflicts, so livings are earned in the Basin in a fashion also fraught with difficulties and challenges. To ensure survival in extremely dry years, or to maximize benefits and minimize waste in more moderate or wet years, water in the Basin is sometimes redistributed using legal water rights transfers.

Feldman's methods focus on establishing watershed-based administrations guided by a rule-based social contract. This would, according to Feldman, replace the capitalist system, narrow interests, and 
property rights system of law and water allocations. However, it is not clear that the regional administration Feldman proposes would look any different from what already exists in the Basin. Feldman does not provide sufficient detail to determine that his suggestion would have a truly different outcome.

Feldman's argument that capitalism and environmentalism cannot co-exist is not convincing given Basin circumstances; both so-called "ethics" are well-represented in the Basin. In fact, individuals seeking to profit from Basin resources also often have high regard for the non-economic values in the Basin. For instance, many ranchers believe that rangeland conditions can be improved with sound grazing practices.

In Oregon, the administration of surface water law is already based on watersheds. Feldman does not clearly specify how water rights would be re-allocated in his system, and therefore it is impossible to determine if eliminating current water rights is either necessary or wise. Water rights in the Basin date back to the early European settlers. Rescinding these rights is not feasible and would threaten the livelihoods of many residents. Also, improved equitability is not, as Feldman believes, impossible under the existing system. For instance, water rights transfer procedures were recently streamlined by the state to provide for more equitable and efficient re-allocation during droughts. 
Although the watershed basins in Oregon are not independent and distinct regions, the usefulness of replacing the existing administrative system with such a region to increase pluralism is not indicated by Basin circumstances. Even assuming that increased pluralism would be beneficial and that it is feasible to replace the existing system, it is not clear that Feldman's system would actually increase pluralism in the Basin.

Planning procedures require public notification and meetings, and public involvement in developing Basin policy is high. For instance, recent plans indicate those private interests involved as individuals, on special committees, and through organizations. Agencies take private-sector recommendations seriously and often adjust plans accordingly (U. S. Bureau of Land Management 1993b; 1992a; U. S. Fish and Wildlife Service 1992; 1990). It does not seem likely that replacing the existing Basin system of overlapping jurisdictions, an involved public, and conflicting interests with Feldman's regional administrations would increase pluralism.

\section{ROGERS' MODEL AND MALHEUR LAKE BASIN}

Rogers believes unrealistic public perceptions and expectations make water policy decisions difficult and administration expensive. Accurately pricing water and centralizing administration will mitigate the effects of unrealistic expectations, claims Rogers. Basin circumstances support 
Rogers' suggestion that perception and expectations can play a major role in water policy. Federal subsidization of public lands and water is expected in the Basin, whether for the support of livestock grazing or of wildlife preservation. Also, there is a perception that it is good policy to attempt to control the natural variability of water. Such expectations and perceptions may well add to the costs of water administration, and strictly adhering to a long-term policy of accounting for complete costs and obtaining payment from users is an intriguing suggestion. However, in the Basin, it is possible that only the wealthiest residents would be able to afford water, whether for agriculture or for wildlife habitat, if a strict policy of payment-for-use were implemented.

\section{Economics}

Costs distribution in the Basin is not entirely in proportion to benefits distribution; federal agencies maintain public lands and some water on those lands but only local and state residents regularly use these resources. Agricultural uses are by far the largest in the Basin. Farmers generally pay for and maintain their own delivery, irrigation, and flood control structures. However, the water-related costs accrued from grazing on public lands in the Basin have not been quantified. Exempt water uses can also be considered to be subsidized, by the state. For example, domestic 
use and stock watering using ground water is not subject to permitting rules (Oregon Water Resources Department 1994). Those on city water supplies are primarily domestic users. These are negligible users of the total Basin water supply, and the water (ground water) is paid for by user fees.

Tourism does not generate significant revenues for agencies administering the public lands where the tourism activities primarily occur (BLM 1986; USFWS 1994). Further, most visitors from outside the Basin are from within Oregon (Bureau of Land Management 1986). This means that federal agency budgets are paying for benefits enjoyed by mostly local and state residents. Federal and state subsidies spread the costs of water and public lands among both users and non-users. However, it is possible that without such subsidies the Basin would support far fewer residents, both people and wildlife.

Rogers does not account at all for an area of crucial concern in the Basin: the natural variability of the water supply. For example, he claims water shortages result from inaccurate pricing, not droughts. He also virtually defines non-economic values out of his model. Rogers believes resources can be managed strictly as commodities, subject to primarily market forces. Rogers' rejects a consideration of water as a public good. However, treating water strictly as a commodity is not practical in the Basin. Natural variability of water is often a serious public nuisance and 
causes occasional disasters in the Basin. Droughts and floods, and the damage associated with these events, cannot feasibly be managed with privatized and market strategies. Entirely private responsibility for water is not feasible in the Basin if the character and current values of the Basin are to be maintained.

Law

In his focus on the regulatory side of law, Rogers' says that ground water and non-point source pollution issues require federal legislation and leadership. Rogers does not explain how the federal government would have legal authority to regulate ground water, which is technically under state juridiction. The state of Oregon has been fairly progressive in developing ground water regulations, and revised ground water rules in 1994 to strictly regulte all drilling of wells and holes (Norris 1994). Also, non-point source pollution from irrigation run-off was not found to be a pressing problem in the Basin (Rinella and Schuler 1992). Erosion is a concern in the Basin, because livestock has depleted deep-rooted vegetation in riparian areas ( $U$. S. Fish and Wildlife Service 1994); however, this is not included in Rogers' model. In any case, it is not certain that the assertion of such federal rules would easily lead state and local agents to implement those rules. 


\section{$\underline{\text { Politics }}$}

Political issues Rogers' mentions include the lack of established, acceptable water quality standards balancing public and environmental health. Rogers' concern is that people's expectations for water quality are unrealistic and that attempting to satisfy these expectations is costly. This concern does not seem to apply to Basin water policy to date because pollution is not currently a problem.

Rogers raises a concern about the maintenance and operations of water infrastructure. These should be federally coordinated and adequately funded, including costs of services as well as of structures, he claims. The infrastructure for Basin water is in variable condition. The five wells serving the cities of Burns and Hines are in good condition, and operations and maintenance are completely funded by user fees. Although a plan exists for strategies should draw-down become a problem, in the last twenty-two years there has been no evidence of overdrafts (Collins 1995). Structures for Malheur National Wildlife Refuge water controls are in poor condition generally, with many control structures dating to the 1950s. Repairs are made as funding allows (Wallsworth 1995). Private irrigation structures are maintained according to individual budgets and preferences. Centralizing the water infrastructure of the Basin does not make sense and is not feasible. Federal control and monitoring of all local water infrastructure 
throughout the nation would be difficult, if not impossible, to establish. This strategy would also only increase subsidization of supplies, which contradicts other aspects of Rogers model that stipulate elimination of such subsidies.

Rogers identifies many problems in interagency and intergovernmental relations. Rogers' believes there are too many organizations with over-lapping authority for development of good water policy. Jurisdictions involved in Basin water policy do not coincide geographically: the state-designated watershed does not coincide with the BLM's Burns District, and neither of these boundaries relate to those of either the national forests or refuges. Multiple agencies with different agendas and geographic extents sharing authority over the same resource can provide valuable balances and trade-offs. This has been demonstrated in the Basin through conflicts over grazing rights, water rights, allocations and use, and wildlife habitat and rangeland improvements (Barnard 1994; Cockle 1994; Cockle 1993; Durbin 1994; Hogan 1994; Wallsworth 1995; U. S. Bureau of Sport Fisheries 1962). Perfect consistency, geographically and ideologically, may not be required for determining the best policy. The centralized administrative system that Rogers proposes is not likely to be feasible in the Basin. Centralization of administration does not guarantee agreement on issues. Further, Rogers does not model the 
relationships between existing jurisdictions, state and federal, and the proposed regional problem-sheds and federal water council. It is possible that, even if increasing coherency and agreement on policy were desirable, applying his proposal in the Basin would only increase conflicts and bureaucracy.

\section{Objectives and Methods}

Rogers' objectives focus on economic and political reforms. He believes beneficiaries should pay complete water costs in a privatized system, organizational roles should be better defined, water policy should be set by a central water authority, and public education should increase awareness of issues. In Malheur Lake Basin, many beneficiaries and users of water resources develop and pay for water and related infrastructure themselves. Other uses are subsidized. A system of paying for complete costs of water might not be practicable, and might prove to be regressive, in the Basin. The resistance of local ranchers to decreased access to public lands for grazing and stock watering, and increased fees for such access, is one indication that eliminating subsidized uses is probably not feasible. The interest of environmentalists in bidding for grazing permits and the purchase of Borax Lake by the Nature Conservancy indicates that some wildlife preservation would occur under a privatized system. However, the 
ability of this community to pay the complete costs of water and maintain the existing land uses and economy is questionable.

Most agency roles are well-defined in the Basin. All federal agencies released management plans within the last five years. The state has not released a Basin-specific plan in thirty years, but has been active in water policy in other ways, such as in developing new drought policies and procedures and new ground water rules. .

Rogers believes that centralization and coordination will improve interagency relations. The two federal agencies in the Basin that "get along", the USFS and the BLM, are under the Departments of Agriculture and Interior, respectively. The agencies that more typically conflict, the USFWS and the BLM, fall under the authority of one department, the Department of Interior. Clearly, centralization under a single federal authority does not guarantee improved coordination if other conflicts exist. In this case, conflicts apparently arise when jurisdictions overlap, especially geographically, regardless of whether agencies are accountable to a single authority.

In the area of improving information and education, particularly directed towards adults, Rogers may have an objective that does not already exist in some form in the Basin and that is not contra-indicated. Education opportunities exist throughout the Basin, including sites for field 
investigations and centers for dissemination of information. These opportunities include the wide variety of Natural Study Areas (under various jurisdictions), Wilderness Study Areas, Refuges, recreation areas, and others. However, no aggressive adult education campaign exists that might provide a means for bridging some of the gaps between ranching and wildlife values. Since Rogers is adverse to subsidies it is important to consider who would pay for such education and research programs. It is likely such an education program is an inconsistency in Rogers' model because it would probably require subsidies. Also, improving public education might not be conducive to the centralized water policy system Rogers seeks. Improved public education implies increased public participation, whereas Rogers seeks to decrease the numbers of parties involved in water policy.

Rogers' methods include establishing meaningful administrative regions. Although the state-defined Basin boundaries do not coincide with the administrative boundaries established by federal authorities, it is nonetheless an arguably meaningful region, albeit one with uncertain boundaries. The physical landscape and political and cultural history make it a region with a recognized and distinctive character. Over time, the Basin has exhibited stability. The economy changes gradually. The conflicts that arise vary somewhat over time, but even these are based on many of the 
same issues and concerns that have dominated conflicts since European settlement of the Basin. It is not clear that adding a problem-shed administration to the existing complex of jurisdictions would add meaning to the region. It is also not clear that it would be consistent with Rogers' goals of consolidating and centralizing water administration. 


\section{CHAPTER V}

\section{CONCLUSION}

Developing theoretical and philosophical ideals for policy is relatively easy. It is more difficult to demonstrate how those ideals relate to actual circumstances and still more difficult to provide a useful framework for actual policy applications. Feldman and Rogers' models over-simplify actual policy concerns, overlook crucial circumstances, and are not feasible for application.

Feldman's normative model assumes capitalism and environmentalism cannot coexist and overlooks historical facts contrary to this. There are examples that these ethics coexist in the Basin, though not without conflict. Feldman seeks social harmony through heightened pluralism. Yet, the Basin demonstrates that well-represented, strongly divergent interests lead to intense conflicts. Trade-offs are wrought through these conflicts, but the conflicts remain. Feldman seeks a broad-based environmental ethic and acceptance of natural variability and uncertainty. However, he does not explain how to achieve this acceptance, overlooking that people depend on predictable, consistent water supplies and that their 
environment can consist of extremely variable conditions, such as those of the Basin.

Rogers, assuming economics factors are primary in water policy, overlooks physical factors, which play a dominant role in water policy. As illustrated in the Basin, non-economic values and concerns are considered seriously in water policy development. Rogers also neglects treatment of flood and drought events, which are prominent concerns in the Basin. His recommendation of managing water entirely as a commodity does not offer any strategy for managing these physical phenomena.

Both models propose a top-down approach to water policy and regional water administrations. Feldman proposes replacing state jurisdiction over water with watershed regions subject to a social contract. Feldman assumes that an environmental ethic can be widely established that would transcend differences and conflicts. Rogers' proposes problemsheds that overlay existing jurisdictions and are subject to a national water council. Rogers' assumes a federal leadership role that transcends local interests. Neither of these scenarios are supported by evidence from the circumstances in the Basin. Establishing either of the regional systems is not feasible given the existing intergovernmental and interagency relations of the Basin. Feldman's system would require replacing existing jurisdictions. Rogers' system does not clarify the relationship of his regional 
administrations to existing jurisdictions. In the Basin, two broad interests, in agriculture and in wildlife habitat, have dominated water policy development since European settlement. Given the level of resistance to policy change, it is not clear that either replacing existing jurisdictions or overlaying additional jurisdictions would be accepted in the Basin. Further, neither model illustrates that its regions would be preferable to, or particularly different from, existing states.

Feldman and Rogers are concerned with establishing an accepted national agenda for water. Feldman seeks increased pluralism and public participation in water policy; however, he prioritizes establishing a nationally-held environmental ethic and a social contract of decisionmaking rules. In Rogers' case, public education is suggested to increase awareness and agreement on a variety of water policy issues. He seeks to manage water coherently through a federal water council and national water policy. It is not feasible to establish such national agendas in the Basin because of state water law. Further, it is not clear that decreased conflict would be necessarily preferable in the Basin. Conflicts between interests in agriculture and in wildlife habitat seem to have led to policy trade-offs and stability in the Basin over time.

The fundamental disagreement between interests in preserving wildlife and in preserving the ranching lifestyle is not likely to be resolved 
by a national agenda. These two interests can coexist, but water policy is often wrought through conflicts and trade-offs. Water policy is unlikely to be generated by getting everyone to believe an environmental ethic or to abide by federal decision. The Basin shows that this is true for agencies as well as individuals. Federal agencies exhibit tension in the Basin. The state periodically resists federal jurisdiction over federal lands and federally-held water rights. Local residents resist changes in federal or state public lands and water policies.

While the Basin is unique in many ways, the issues and concerns present there can be generalized to other locations. In particular, the conflicts between agricultural and environmental values and the difficulties with variable water supplies are circumstances that occur in many areas. These are precisely the issues that the models do not accurately represent. Neither model offers a framework adequate for considering natural factors and physical variability of water supplies. However, in the Basin, natural factors are a crucial water policy concern. Also significantly, neither of the regional systems of water administration recommended by the models is applicable to the Basin. It is doubtful, therefore, that the models would provide useful frameworks in other locations.

These two models do not provide sufficient frameworks for Basin water policy applications because they do not adequately account for and 
reflect the circumstances of the Basin. While models are necessarily simplifications, the models considered herein suffer from extreme oversimplification. Model development is not necessarily a useless endeavor. Ideally, models can provide applicable frameworks. However, in order to provide useful frameworks for water policy applications, model developers must closely consider the circumstances of actual water policy cases, rather than idealize and debate theoretical and philosophical issues. 


\section{BIBLIOGRAPHY}

Anderson, T. 1983. Water crisis: Ending the Policy Drought. Baltimore: Johns Hopkins University Press.

Anonymous. 1902. An Illustrated History of Baker, Grant, Malheur and Harney Counties: With a Brief Outline of the Early History of the State of Oregon. Portland, Oregon: Western Historical Publishing Company.

Anonymous. 1995. They Are Federal Lands. The Oregonian. B02. January 15.

Baldwin, E. M., Orr, E. L., and Orr, W. N. 1992. Geology of Oregon. Dubuque, Iowa: Kendall/Hunt Publishers.

Barnard, J. 1994. Ranchers Win Ruling on Grazing. The Oregonian. C02. December 22.

Bentley, G. 1995. Environmental Coordinator, Burns District, U. S. Bureau of Land Management. Interview with Author. May 18.

Benyus, J. M. 1989. The Field Guide to Wildlife Habitats of the Western Unites States. New York: Simon \& Schuster, Inc.

Brimlow, G. F. 1951. Harney County, Oregon, and Its Rangeland. Portland, Oregon: Bindfords \& Mort Publishers.

Carson, R. 1962. Silent Spring. New York: Fawcett Crest.

Ciriacy-Wantrup, S. V. 1963. Resource Conservation: Economics and Policies. Berkeley: University of California Press.

Cockle, R. 1993. The Rough Road to Controversy. The Oregonian. B01. August 1.

.1994. PGE Negotiates Alvord Desert Geothermal Power Plant. The Oregonian. D02. May 4. 
Cohon, J. L. 1978. Multiobjective Programming and Planning. Mathematics in Science and Engineering, vol. 140. New York: Academic Press.

Collins, D. 1995. Director of Public Works, City of Burns. Interview with Author. October 10.

Columbia-North Pacific Technical Staff. 1970. Columbia-North Pacific Region Comprehensive Framework Study: On Water and Related Lands. 18 Vols. Vancouver, Washington: Pacific Northwest River Basins Commission.

Doppelt, B., Scurlock, M., Frissell, C., and Karr, J. 1993. Entering the Watershed: A New Approach to Save America's River Ecosystems. Washington, D. C.: Island Press.

Duebbert, H. F. 1969. The Ecology of Malheur Lake and Management Implications. Burns, Oregon: U.S. Department of the Interior, Bureau of Sport Fisheries and Wildlife.

Durbin, K. 1994. Babbitt Meets with Ranchers, Drops Some Rangeland Proposals. The Oregonian. D01. February 17.

Eckstein, O. 1958. Water Resources Development: The Economics of Project Evaluation. Harvard University Press, Cambridge, Massachusetts.

Feldman, D. L. 1991. Water Resources Management: In Search of an Environmental Ethic. Baltimore, Maryland: Johns Hopkins University Press.

Franklin, J. F., Hall, F. C., Dyrness, C. T., and Maser, C. 1972. Federal Research Natural Areas in Oregon and Washington: A Guidebook for Scientists and Educators. Washington, D. C.: U. S. Department of Agriculture Forest Service.

Freeze, R. A., and Cherry, J. A. 1979. Ground Water. New Jersey: PrenticeHall.

French, Giles. 1964. Cattle Country of Peter French. Portland, Oregon: Binfords \& Mort Publishers.

Fuste, L. A., and McKenzie, S. W. 1987. Water Quality of the Malheur Lake System and Malheur River, and Simulated Water-quality Effects of 
Routing Malheur Lake Water into Malheur River, Oregon, 1984-85.

Portland, Oregon: U. S. Geological Survey Water Resources

Investigations Report 86-4202.

Gonthier, J. B. 1985. A Description of Aquifer Units in Eastern Oregon.

Portland, Oregon: U. S. Geologic Survey Water Resources Investigations Report 84-4095.

Gottleib, R. 1988. A Life of Its Own: The Politics and Power of Water. New York: Harcourt Brace Joanovich Publishers.

Hanke, S. H., and R. Davis. 1973. Potential for Marginal Cost Pricing in Water Resources Management. Water Resources Research 9(4):808-825.

Hogan, D. 1994. Father, Son Plead Innocent in Malheur Water Dispute. The Oregonian. C06. November 5.

Holmes, B. H. 1972. A History of Federal Water Resources Programs, 18001960. Washington, D. C.: U. S. Department of Agriculture, Economic Research Service Paper PB-295 733.

- 1979. History of Water Resources Programs and Policies, 1961-1970. Washington, D. C.: U. S. Department of Agriculture, Economics, Statistics, and Cooperative Service Miscellaneous Publication no. 1379.

Horton, S. K., Littlefield, C. D., Paulin, D. G., and Vorderstrasse, R. E. 1983. Migratory Bird Populations and Habitat Relationships in MalheurHarney Lakes Basin, Oregon. Portland, Oregon: U. S. Fish and Wildlife Service.

Hubbard, L. L. 1975. Hydrology of Malheur Lake, Harney County, Southeastern Oregon. Portland, Oregon: U. S. Geological Survey Water Resources Investigations 21-75.

-1989. 1984 Flooding of Malheur-Harney Lake, Harney County, Southeastern Oregon.. Portland, Oregon: U. S. Geological Survey Water Resources Investigations 89-4111.

James, L. D., and Lee, R. R. 1971. Economics of Water Resources Planning. New York: McGraw-Hill. 
Kellert, S. R., and Bormann, F. H., eds. 1991. Ecology, Economics, Ethics: The Brocken Circle. New Haven: Yale University Press.

Klingeman, P. C., Bond, C. E., Cole, B. J., Shearer, M. N., Smith, C. L., H. M. Wight, and Youmans, R. C. 1971. Environmental Considerations and the Watre Resources of the Silvies Basin. Corvallis, Oregon: Army Corps of Engineers, Water Resources Research Institute, Oregon State University.

Leonard, A. R. 1970. Ground Water Resources in Harney Valley, Harney County, Oregon. Salem, Oregon: State Water Resources Board Ground Water Report No. 16.

Littlefield, C. D. 1990. Birds of Malheur National Wildlife Refuge, Oregon. Corvallis, Oregon: Oregon State University.

Maass, A.. 1951. Muddy Waters: The Army Engineers and the Nation's Rivers. Cambridge, Massachusettes: Harvard University Press.

- 1962. The Design of Water Resources Systems: New Techniques for Relating Economic Objectives, Engineering Analysis, and Governmental Planning. Cambridge, Massachusettes: Harvard University Press.

Mann, D. E. 1975. Political Incentives in U. S. Water Policy: Relationships between Distributive and Regulatory Politics. In What Government Does, eds. M. Holden, Jr. and D. L. Dresang, pp. 95-123. Beverly Hills: Sage Publications.

Mathews, O. P. 1984. Water Resources, Geography, and Law. Washington, D. C.: Association of American Geographers.

Moore, R. J. 1988. Systems Analysis Approach to Modelling of Surface and Ground Water Resources. In Systems Analysis Applied to Management of Water Resources: Selected Papers from the 4th IFAC Symposium, Rabat, Morocco, 11-13 October 1988. ed. Jellali, M. New York: Pergamon Press.

Moreell, B. 1956. Our Nation's Water Resources, Policies, and Politics. Chicago: University of Chicago Press.

National Groundwater Policy Forum. 1987. Groundwater: Saving the Unseen Resources. Washington D. C.: Conservation Foundation. 
National Research Council. 1992. Restoration of Aquatic Ecosystems. Washington, D. C.: National Academy of Science.

National Water Commission. 1973. Final Report, Water Policies for the Future. Port Washington, New York: Water Resource Information Center.

Norris, Barry. 1994. Administrator, Technical Services, Oregon Water Resources Department. Interview with Author. July 1.

North, R. M., Dworsky, L. B., and Allee, D. J. 1981. Unified River Basin Management: Procedings of a Symposium Held in Gatlinburg, Tennessee, May 4-7, 1980. 2 vols. Minneapolis, Minnesota: American Water Resources Association.

Oregon Water Resources Department. 1992. Biennial Report. Salem, Oregon: Oregon Water Resources Department.

1994. Oregon's Water Rights System. Salem, Oregon: Oregon Water Resources Department.

- 1995. 1995-1999 Strategic Water Resource Management Plan. Salem, Oregon: Oregon Water Resources Department.

Organization for Economic Co-operation and Development. 1989. Water Resource Management: Integrated Policies. Paris: Organization for Economic Co-operation and Development.

Otley, Fred. 1994. Rancher. Presentation. May 7.

Paulson, R. W., Chase, E. B., Roberts, R. S., and Moody, D. W. 1991. National Water Summary 1988-89: Hydrologic Events and Floods and Droughts. Denver: U. S. Geological Survey Water Supply Paper 2375.

Phillips, K. N., and Van Denburgh, A. S. 1971. Hydrology and geochemistry of Abert, Summer, and Goose Lakes, and other closed basin lakes in Southcentral Oregon. Washington, D. C.: U. S. Geologic Survey Professional Paper 502-B.

Piper, A. M. 1939. Geology and Ground Water Resources of the Harney Basin, Oregon. Washington, D. C.: U. S. Geological Survey Water Supply Paper, 841. 
Platt, R. H. 1995. The 2020 Water Supply Study for Metropolitan Boston: The Demise of Diversion. Journal of American Planning Association 61(2):185-199.

- 1993. Water Demand Management. Environment 35(3):2-3.

Reinhardt, Richard. 1992. Desert Storm: From Horst to Graben, Plains to Uplands, Oregon's High Desert Finds Itself Hostage to Tradition and Controversy. Wilderness 56:10-22.

Reisner, M. 1986. Cadillac Desert: The American West and Its Disappearing Water. New York: Viking.

- and Bates, S. 1990. Overtaped Oasis: Reform or Revolution for Western Water. Washington, D. C.: Island Press.

Reuss, M., ed. Water Resources Administration in the United States: Policy, Practice, and Emerging Issues: Selected Papers from the American Water Resources Association National Forum on Water Management Policy, June 28-July 1, 1992, Washington, D. C. East Lansing, Michigan: American Water Resources Association and Michigan State University Press.

Riggins, R. E., Jones, E. B., Singh, R., and Rechard, P. A., eds. 1990. Watershed Planning and Analysis in Action: Procedings of the Symposium Sponsored by the Committee on Watershed Management of the Irrigation and Drainage Division of the American Society of Civil Engineers in conjunction with the ASCE Irrigation and Drainage Conference in Durango, Colorado. New York: American Society of Civil Engineers.

Rinella, F. A., and Schuler, C. A.. 1992. Reconnaissance Investigation of Water Quality, Bottom Sediment, and Biota Associated with Irrigation Drainage in the Malheur National Wildlife Refuge, Harney County, Oregon, 1988-1989. Portland, Oregon: U. S. Geoglocial Survey Water Resources Investigations Report 91-4085.

Rogers, P. 1993. America's Water: Federal Roles and Responsibilities. Cambridge: MIT Press.

Rohse, M. 1987. Land-use Planning in Oregon: A Non-nonsense Handbook in Plain English. Corvallis, Oregon: Oregon State University Press. 
Sewell, W. R. D. 1965. Water Management and Floods in the Frasier River Basin. Chicago: University of Chicago Press.

Simpson, P. K. 1987. The Community of Cattlement: A Social History of the Cattle Industry in Southeastern Oregon, 1869-1912. Moscow, Idaho: University of Idaho Press.

State Water Resources Board (Oregon). 1967. Malheur Lake Basin. Salem, Oregon: State Water Resources Board.

U. S. Army Corps of Engineers. 1957. Survey Report on Silvies River and Tributaries, Oregon. Portland, Oregon: U. S. Army Corps of Engineers.

1987. Malheur Lake flood damage reduction study, Harney County, Oregon: Final Feasibility Report and Environmental Impact Statement. 2 vols. Walla Walla, Washington: U. S. Army Corps of Engineers.

U. S. Bureau of Land Management. 1982. Andrews Resource Area Management Framework Plan. Hines, Oregon: U. S. Bureau of Land Management.

1986. Program Direction: Oregon and Washington. Portland, Oregon: U. S. Bureau of Land Management.

1989. Riddle Brothers Ranch National Historic District Cultural Resource Management Plan. Hines, Oregon: U. S. bureau of Land Management.

1992a. National Wild \& Scenic River Donner und Blitzen: Management Plan, Environmental Assessment. Hines, Oregon: U. S. Bureau of Land Management.

1992b. Three Rivers Resource Management Plan, Record of Decision, and Rangeland Program Summary. Hines, Oregon: U. S. Bureau of Land Management.

1993a. Wilderness Program: Burns District: Tips for Using Wilderness Study Areas. Hines, Oregon: U. S. Bureau of Land Management.

1993b. Andrews Plan Ammendment for Recreation Access Surrounding the Steens Mountain Loop Road: Environmental Assessment 
to the Proposed Plan Ammendment for the Andrews Management Framework Plan. Hines, Oregon: U. S. Bureau of Land Management.

U. S. Bureau of Sport Fisheries, 1962. Report on the Water Rights, Water Supply, Water Distribution, and Water Use of Malheur National Wildlife Refuge, Oregon. Washington, D. C.: U. S. Department of the Interior.

U. S. Department of Commerce, Bureau of the Census. 1913a. Thirteenth Census of the United States: Vol. III: Population. Washington, D. C.: Goverment Printing Office.

1913b. Thirteenth Census of the United States: Vol. VII: Agriculture. Washington, D. C.: Goverment Printing Office.

1922a. Fourteenth Census of the United States Taken in the Year 1920: Vol. VII: Irrigation and Drainage. Washington, D. C.: Government Printing Office.

1922b. Fourteenth Census of the United States Taken in the Year 1920: Vol. IV: Population. Washington, D. C.: Government Printing Office.

1984. 1982 Census of Agriculture: Vol. I: Geographic Area Series. Washington, D. C.: Government Printing Office.

1993a. 1990 Census of Population and Housing: Census Tracks and BNAs: Oregon. Washington, D. C.: Government Printing Office.

1993b. 1992 Census of Agriculture: Vol. I: Geographic Area Series. Washington, D. C.: Government Printing Office.

U. S. Fish and Wildlife Service. 1982. National Wildlife Refuge System Refuge Manual. Washington, D. C.: U. S. Department of Interior, Fish and Wildlife Service.

1985. Malheur National Wildlife Refuge Master Plan and Environmental Assessment. Princeton, Oregon: U. S. Fish and Wildlife Service.

1990. Blitzen Valley Management Plan: Malheur National Wildlife Refuge, Oregon. Princeton, Oregon: U. S. Fish and Wildlife Service. 
1992. Habitat Monitoring and Inventory Plan: Malheur National Wildlife Refuge, Oregon. Princeton, Oregon: U. S. Fish and Wildlife Service.

-1994. Hart Mountain National Antelope Refuge Comprehensive Management Plan: Final Environmental Impact Statement. 2 Vols. Portland, Oregon: U. S. Fish and Wildlife Service.

U. S. Forest Service. 1991. Land Management Plans in the Pacific Northwest Region. Portland, Oregon: U. S. Forest Service.

Vorderstrasse, R. E., and Garst, R. L. 1987. Impacts of the Proposed Malheur Lake Flood Damage Reduction Measures on Fish and Wildlife Resources. Portland, Oregon: U. S. Army Corps of Engineers.

Wallsworth, D. 1995. Assistant Deputy Manager, Malheur National Wildlife Refuge. Interview with Author. May 19.

Welsh, F. 1985. How to Create a Water Crisis. Boulder, Colorado: Johnson Books.

White, G. F. 1969. Strategies of American Water Management. Ann Arbor, Michigan: University of Michigan Press.

-1986. Selected Writing of Gilbert $F$. White. Resources, and Environment, vol. 1, R. W. Kates and I. Burton eds. Chicago: University of Chicago Press.

- 1988. The Environmental Effects of the High Dam at Aswan. Environment 30(7):4-11.

- 1991.The Wetlands Controversy. Environment 33(9): editorial.

Wilkinson, C. F. 1990. Crossing the Next Meridian: Sustaining the Lands, Water, and Human Spirit in the West. Environment 30(10)14-20.

Wolman, N., and Bonem, G. E. 1971. The Outlook for Water-quality, Quantity and National Growth. Baltimore., Maryland: Johns Hopkins University Press. 